\title{
La consécration qui ne vient pas
}

Réduction, ajustement et conversion des aspirations des artistes ordinaires du spectacle

A Consecration That Never Comes. Reduction, Adjustment and Conversion of Aspirations among Ordinary Performing Artists

La consagración que no llega. Reducción, ajuste y conversión de las aspiraciones de los artistas ordinarios del espectáculo

Jérémy Sinigaglia

\section{(2) OpenEdition} Journals

Édition électronique

URL : http://journals.openedition.org/bssg/101

DOI : $10.4000 /$ bssg. 101

ISSN : 2490-9424

Éditeur

Presses universitaires de Vincennes

Référence électronique

Jérémy Sinigaglia, "La consécration qui ne vient pas », Biens Symboliques / Symbolic Goods [En ligne], 1 | 2017, mis en ligne le 15 octobre 2017, consulté le 04 mars 2021. URL : http:// journals.openedition.org/bssg/101; DOI : https://doi.org/10.4000/bssg.101 

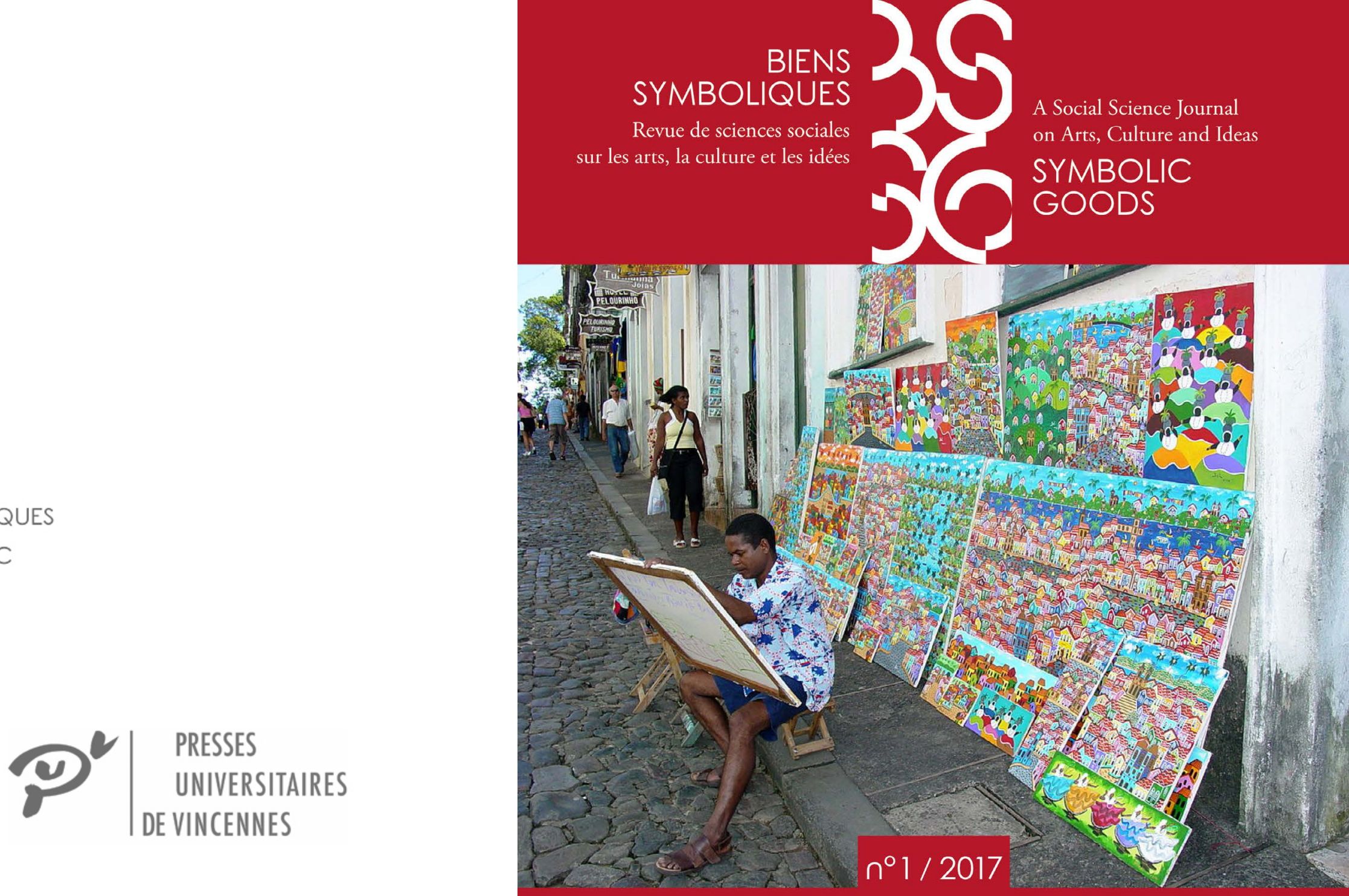

\section{Artistes ordinaires \\ Ordinary Artists}




\title{
La consécration qui ne vient pas \\ Réduction, ajustement et conversion des aspirations des artistes ordinaires du spectacle \\ A Consecration That Never Comes \\ Reduction, Adjustment, and Conversion of Aspirations among Ordinary Performing Artists
}

\author{
Jérémy Sinigaglia \\ traduction | translation \\ Jean-Yves Bart
}

«Bonjour à toutes et tous,

C'est décidé, j'arrête de chercher à partager mon univers artistique avec le public, à être compris et à percer... Décision qui n'intéressera d'ailleurs personne !! ! L'accumulation de problèmes personnels, des soucis de santé incompris qui provoquent marginalisation, stigmatisation et rejet... me font vivre l'isolement et la solitude depuis bien trop longtemps. Si on ajoute la rudesse du public, du milieu artistique et musical qui jugent bien souvent à l'emporte-pièce, sans savoir réellement de quoi ils parlent avec en plus des coups-bas et également des attitudes poussant

à l'isolement et à la mise en quarantaine... J'ai décidé de tout arrêter pour prendre soin de moi au lieu de me laisser détruire par une indifférence et un rejet presque systématiques. [...]

Bonne continuation à toutes et tous! 》 Yohan, message électronique du 4 mai 2016
"Hello everyone,

I've made up my mind to stop trying to share my artistic universe with an audience, to be understood and to get a break... I know full well that nobody's interested in my decision either!!! Due to mounting personal problems and misunderstood health issues that lead me to be marginalized, stigmatized and rejected, I have lived in isolation and solitude for far too long. Not to mention the rudeness of the audience, of the art and music worlds where people make snap judgments without really knowing what they're talking about, and also the low blows and attitudes that force people into isolating and quarantining themselves... I've decided to give it all up to take care of myself instead of letting that continual indifference and rejection destroy me...

I wish you all well."

Yohan, email dated 4 May 2016. 


\section{Introduction}

Ce message, envoyé par un artiste $^{1}$ à l'ensemble de ses contacts, illustre l'une des issues possibles des carrières artistiques marquées, entre autres, par l'absence de reconnaissance ou de succès ${ }^{2}$. La sortie de carrière est en effet fréquente dans ce type de professions : environ un quart des artistes quittent le marché du travail artistique dans les deux ans qui suivent leur premier contrat et plus de la moitié le quittent dans les cinq ans (Cardon 2011). Pour autant, l'accumulation des difficultés, qu'elles soient d'ordre socioéconomique (précarité de l'emploi, revenus faibles et variables, problèmes d'accès au logement voire aux soins, etc.) ou professionnel (déficit d'intégration dans les réseaux professionnels, manque de ressources efficientes, absence de reconnaissance, etc.), ne conduit pas systématiquement les artistes concernés à mettre fin à leur carrière.

1 Né en 1981, bénéficiaire du revenu de solidarité active, il a tenté de vivre de la musique pendant une dizaine d'années en cumulant, sous différents pseudonymes, activité musicale (rap, plusieurs titres et EP en ligne), plastique (peinture, quelques expositions locales en marge du champ artistique) et littéraire (poésie, trois recueils publiés à compte d'auteur).

2 Comme le notent Wenceslas Lizé, Delphine Naudier et Séverine Sofio, le lexique des rétributions sur le marché des biens symboliques est varié : «Certaines notions désigneront alors plutôt la valeur symbolique (reconnaissance, consécration, etc.) et seront privilégiées dans l'étude de la "sphère de production restreinte", tandis que d'autres renverront davantage à la valeur médiatique ou commerciale (notoriété, célébrité, succès, etc.) et sont plus appropriées pour l'étude de la "sphère de grande production" (Lizé, Naudier et Sofio 2014).

\section{Introduction}

This message sent by an artist ${ }^{1}$ to his entire list of contacts illustrates one of the possible outcomes for artistic careers characterized by a lack of recognition or success ${ }^{2}$. Exit is frequent in these occupations: roughly one in four artists leave the artistic job market within two years after their first job, and over half leave within five years (Cardon 2011). Still, the accumulation of hardships, be they socioeconomic (insecure employment, low and irregular income, issues with access to housing and healthcare, etc.) or professional (a lack of integration into professional networks, efficient resources, recognition, etc.), does not automatically lead these artists to end their careers.

1 Born in 1981, and a recipient of the revenu de solidarité active [RSA-currently the main French minimum benefit], Yohan attempted to make a living from his art for around ten years. Under several pseudonyms, he worked in music (several rap songs and an online EP), visual arts (painting, with a few local exhibitions on the fringes of the art world), and literature (three self-published poetry collections).

2 As Wenceslas Lizé, Delphine Naudier, and Séverine Sofio have observed the vocabulary of rewards in the market of symbolic goods is quite varied: "Some concepts refer primarily to symbolic value (such as recognition, and consécration [the French term referring to one's establishment within a particular field, translated here as 'consecration']) and should be favoured in the study of 'spheres of restricted production;' whereas others relate to the media or market value (exposure, fame, success, etc.) and are more appropriate to the study of 'spheres of large-scale production"' (Lizé, Naudier, Sofio 2014). 
L'article propose de s'intéresser aux trajectoires de ces artistes que l'on peut, à la suite de Marc Perrenoud, qualifier “ d'ordinaires ». Cette désignation ne renvoie pas à un jugement sur la qualité de leur production, sur leurs capacités ou leur supposé talent mais, d'une part, à leurs conditions de travail et d'emploi et, d'autre part, à la position qu'ils occupent dans l'espace professionnel ${ }^{3}$. Par opposition aux vedettes ou aux stars du show-business, les artistes ordinaires ne connaissent « ni la fortune ni la gloire » (Perrenoud $2007: 8$ ). Exerçant principalement leur métier sous le régime d'emploichômage des intermittents (plus rarement sous le statut d'auto-entrepreneur, voire de bénéficiaire de minima sociaux pour les moins intégrés professionnellement), leur activité est généralement irrégulière, difficilement prévisible et génère des revenus relativement faibles ${ }^{4}$. Ils sont très souvent confrontés à la multiactivité (Bureau, Perrenoud, Shapiro 2009), exerçant une ou plusieurs activités secondaires à l'intérieur ou à l'extérieur du champ artistique. Évoluant à distance des pôles dominants du champ artistique, ils n'accèdent que rarement ou partiellement aux différentes formes de consécration, que ce soit celle des pairs (principe de hiérarchisation interne du champ artistique) ou du public (principe de hiérarchisation externe), qui constituent l'enjeu central du marché des biens symboliques (Bourdieu 1971).

3 Au sens de l'espace social en tant qu'abstraction théorique (l'espace des positions et des relations entre les agents) mais aussi en tant qu'espace social réifié (un territoire, local ou national) (Bourdieu 1993).

4 Le revenu médian des artistes du spectacle est d'environ 22000 euros par an, constitué pour moitié d'indemnités chômage (soit environ 1800 euros par mois, contre un peu moins de 1700 euros mensuels pour l'ensemble des français) (Gouyon et Patureau 2014).
This paper focuses on ordinary artists, under the definition proposed by Marc Perrenoud. This term does not imply a judgment on the quality of their output, skills, or supposed talent; it refers first to their working and employment conditions, and second to their position in the professional space $^{3}$. Unlike the stars of show business, ordinary artists know "neither fortune nor glory" (Perrenoud 2007: 8). In France, the majority work as intermittents (contract workers in the entertainment industry); some are self-employed as autoentrepreneurs (a recently introduced, simplified freelance status), and a few of the least professionally integrated live on minimum benefits. Their activities are generally irregular, difficult to schedule, and generate fairly low income ${ }^{4}$. These people very often have multiple jobs (Bureau, Perrenoud, Shapiro 2009), with one or two secondary activities inside or outside the artistic field. They are far removed from the dominant poles of the artistic field, and only rarely or partially gain access to the forms of consecration available in the field consecration by peers (in the internal hierarchy of the field) or by the public (in its external hierarchy)-which are the main prizes in the market of symbolic goods (Bourdieu 1985). These ordinary artists may have varying trajectories, be "young intellectuals, old proles, or the other way around" (Perrenoud 2007: 8), but this paper mostly examines artists

3 In the sense of a social space as theoretical abstraction (the space of positions and relationships between individuals) but also of a reified socia space (a local or national territory) (Bourdieu 1999).

4 The median income of performing artists in France is around 22,000 euros/ year, half of which comes from unemployment benefits. This amounts to roughly 1,800 euros/month, versus slightly under 1,700 euros/month for French workers in general (Gouyon, Patureau 2014) 
Si ces artistes ordinaires peuvent avoir des parcours variés, être « des jeunes intellectuels, des vieux prolétaires ou l'inverse » (Perrenoud $2007: 8$ ), il sera ici surtout question d'artistes aux origines sociales modestes. D'abord parce que ce sont eux qui occupent le plus souvent les positions les plus dominées du champ artistique ${ }^{5}$. Ensuite, parce que c'est pour eux, socialisés le plus souvent à distance du champ artistique, que l'écart entre les espérances subjectives et les chances objectives est le plus important : plus le degré de connaissance des réalités de la vie d'artiste est faible, plus les représentations que s'en font les agents tendent à être idéalisées et plus la confrontation avec la réalité peut être difficile, générer un sentiment de déception ou de frustration et, dans certains cas, conduire à la sortie.

L'objectif de cet article est de montrer ce qui se passe lorsque les attentes qui ont nourri l'engagement dans un métier à vocation ne sont pas satisfaites. Comment expliquer le maintien dans la carrière des artistes ordinaires, malgré des conditions objectives d'existence relativement précaires et des rétributions symboliques souvent insuffisantes pour les compenser ? On fait ici l'hypothèse que la carrière des artistes ordinaires tient en partie à leurs facultés très inégales de jouer avec leurs aspirations. En effet, si dans les cas les plus fréquents de reproduction sociale on peut observer « une correspondance immédiate entre les structures et les habitus » (Bourdieu 1974 : 5), lorsque les contextes de socialisation sont très différents des espaces sociaux

5 Sur les inégalités liées à l'origine de classe dans les carrières artistiques, voir par notamment Brook 2013 ; Friedman et al. 2016. from humble social backgrounds. This is firstly because they are the ones who most often hold dominated positions in the artistic field ${ }^{5}$. Secondly, as they have generally been socialized outside the artistic field, the gap between subjective aspirations and objective chances is the widest them: the less one knows about the reality of an artist's life, the more one's representations tend to be idealized, making it difficult to face reality, and leading to feelings of disappointment, frustration, and in some cases, career exits.

The objective of this paper is to show what happens when expectations which spurred engagement in a vocational occupation are not met. Why do artists continue their careers despite relatively precarious "objective" living conditions and often insufficient symbolic rewards to make up for them? This paper proposes the hypothesis that the careers of ordinary artists are largely shaped by very unequal abilities to exploit their aspirations. While in the most frequent cases of social reproduction there is an "immediate correspondence between structures and habitus" (Bourdieu 1974: 5), when the sites of socialization widely differ from the social spaces in which individuals enter or aspire to enter, the correspondence is less immediate and depends on the agent's dispositions

5 On class background-related inequalities in artistic careers, see for instance Brook (2013); Friedman et al. (2016). 
convoités ou atteints, l'ajustement est moins automatique et sa réalisation varie selon les dispositions et les ressources de l'agent. Ce processus, marqué par l'apprentissage des règles qui structurent l'espace professionnel, par les succès et les échecs aux différentes épreuves et par les relations avec les pairs, va permettre, ou non, à un artiste de trouver " sa place », c'est-à-dire d'aspirer à ce qui est objectivement probable et de rejeter subjectivement ce qui est objectivement inaccessible (Bourdieu 1980).

Focaliser l'analyse sur les trajectoires d'artistes ordinaires, en particulier sur ceux aux origines sociales modestes, permet ainsi de mettre au jour une série de mécanismes qui concourent à la production et à la reproduction des inégalités sociales dans les carrières artistiques. Alors même que le champ artistique se présente comme un " marché ouvert " (Paradeise 1998) et se caractérise par la faiblesse apparente des « droits d'entrée » (Mauger 2006a), l'observation montre que les moins bien dotés, souvent moins bien nés, en sont rapidement exclus ou sont assignés aux positions dominées. Non seulement ces artistes partagent un certain nombre de propriétés et d'expériences sociales qui ne les prédisposent pas à accéder aux positions dominantes mais, plus encore, celles-ci les poussent à adopter des conduites, des stratégies, qui vont renforcer leur destin probable d'artistes ordinaires.

Le plan de la démonstration suit, comme le préconise Everett Hughes (1996), les étapes de la carrière : comment on y entre, comment on s'y maintient et comment on en sort. Chacune de ces séquences est l'occasion d'observer ce que l'on pourrait appeler le travail des aspirations : leur réduction, qui and resources. The process of learning the rules which structure the professional space, through trial and error and in relationships with peers, allows artists to find (or not) their own "place"-meaning they to aspire to objectively likely outcomes, and subjectively reject what is objectively inaccessible (Bourdieu 1990).

By focusing on the trajectories of ordinary artists, and particularly those with humble backgrounds, I unveil several mechanisms involved in the production and reproduction of social inequalities in artistic careers. Although the artistic field presents itself as an "open market" (Paradeise 1998) with seemingly small "costs of entry" (Mauger 2006a), observation shows that those with the least capital, often from less privileged backgrounds, are quickly excluded from it or assigned to dominated positions. Not only do these artists share a number of social properties and experiences that do not predispose them to accessing dominant positions, but these properties also lead them to adopt behaviours and strategies that reinforce the likelihood of becoming ordinary artists.

Following the recommendation of Everett Hughes (1996), the structure of this paper follows the stages of a career: entry, maintenance, and exit. Each of these stages provides an opportunity to observe aspirations at work: first, they are reduced, so that inaccessible childhood dreams do not 
permet d'éviter que les inaccessibles « rêves de môme » ne constituent un obstacle insurmontable dès l'entrée en carrière (1) ; leur ajustement, qui conduit à formuler des attentes en phase avec les chances objectives de les voir se réaliser au cours de la carrière (2) ; leur transfert dans un nouveau projet professionnel, qui limite les coûts d'une reconversion professionnelle lorsque le maintien dans la carrière artistique n'est plus possible (3).

\footnotetext{
Terrain et méthode

L'article repose principalement sur un matériau constitue au cours de deux enquêtes par entretiens $(N=74$ et $N=14)$, réalisés entre 2010 et 2012, interrogeant les trajectoires et les conditions de travail et d'emploi d'artistes « ordinaires » du spectacle vivant (musique, théâtre, danse et cirque). Les enquêtes ont été menées en Alsace et en Lorraine, dans des espaces professionnels régionaux relativement éloignés des pôles dominants du champ artistique. La sélection des interviewés a tenu compte de cinq variables principales : le sexe, le métier, le secteur d'activité, le degré d'intégration professionnelle (qui agrège divers indicateurs tels que le statut d'emploi, le moment dans le cycle professionnel, le niveau de salaire, etc.) et le lieu d'ancrage professionnel (afin d'éviter les biais liés aux configurations locales). Ces recherches ont bénéficié du soutien du Département des études de la prospective et des statistiques du ministère de la Culture (DEPS) et ont donné lieu à deux rapports : Être heureux dans l'emploi culturel. Qualité de l'emploi et du travail des femmes et des hommes du spectacle vivant, 2011 et Le rapport au territoire des équipes artistiques. Cartographie socio-ethnographique du spectacle vivant, 2012.
}

constitute an insurmountable obstacle from the early days of their career (1); then, they are adjusted to formulate expectations that match their objective chances of success during in their career (2); and ultimately they are converted into a new career plan, limiting the costs of a career change when sustaining an artistic career is no longer possible (3).

\section{Fieldwork and methodology}

This paper is mostly based on material gathered during two stages of interview $(\mathrm{N}=74$ and $\mathrm{N}=14)$ conducted between 2010 and 2012. The interviews were designed to examine the trajectories and the working and employment conditions of ordinary performing artists (in music, theatre, dance, and circus). They took place in the north-eastern French regions of Alsace and Lorraine in professional spaces situated relatively far from the dominant poles of the artistic field. Interviewees were selected according to five main variables: gender; occupation; sector of activity; degree of professional integration (a combination of indicators including employment status, career stage, income level, etc.); and main place of work (to avoid bias relating to local settings). This research was supported by the French Ministry of Culture's department for studies, strategic foresight and statistics. Findings are summarized in two reports: "Être heureux dans l'emploi culturel. Qualité de l'emploi et du travail des femmes et des hommes du spectacle vivant" (2011) and "Le rapport au territoire des équipes artistiques. Cartographie socioethnographique du spectacle vivant" (2012). 


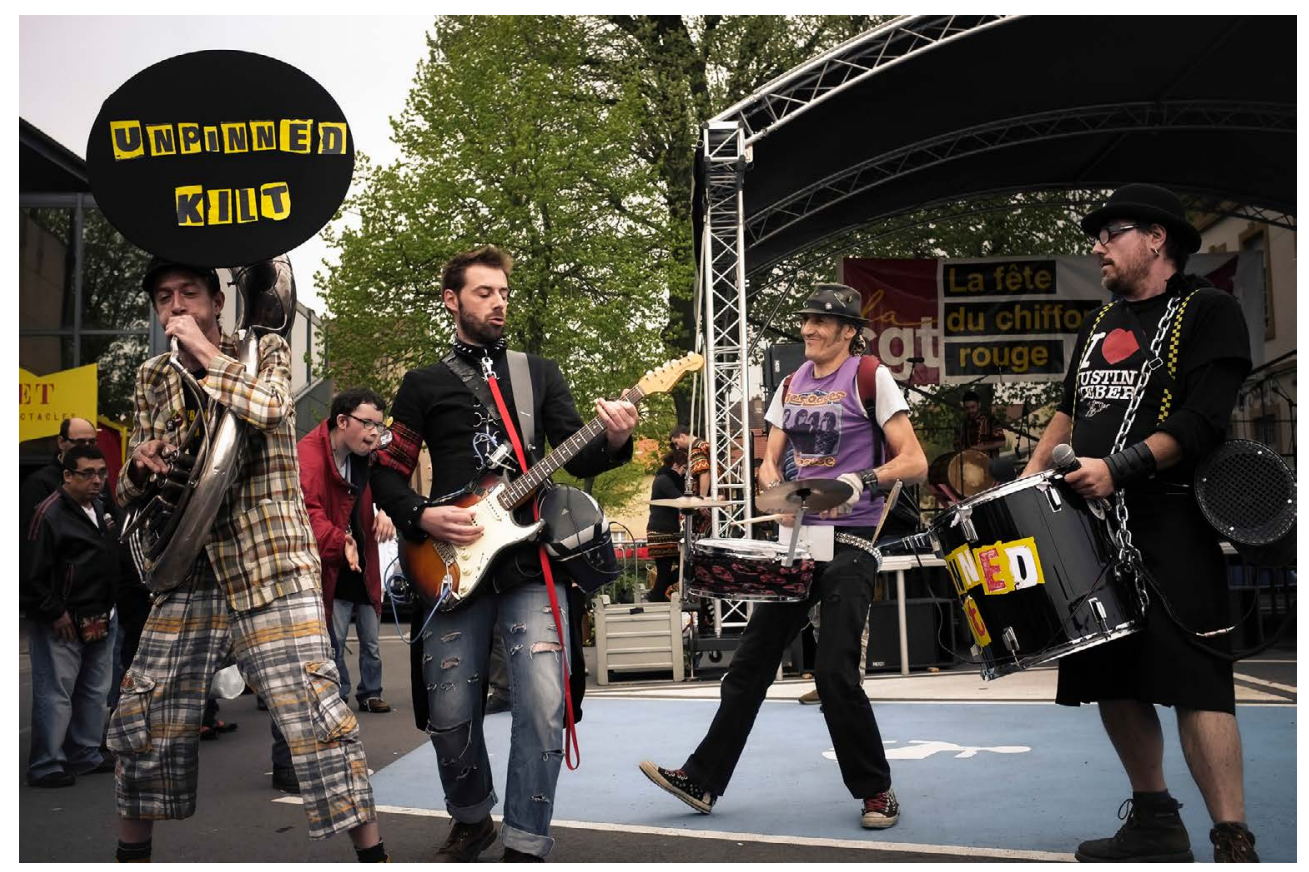

Musiciens lors d'une fête syndicale

Musicians during a union party

(c) Jérémy Sinigaglia

\section{La nécessaire acquisition du « sens des limites"}

L'entrée en carrière est une période décisive dans la vie professionnelle des artistes du spectacle, en particulier pour ceux qui n'ont pas eu l'occasion d'acquérir, au cours de leur socialisation, les dispositions adaptées au champ artistique.

\section{The necessary acquisition of a "sense of boundaries"}

Career entry is a decisive time in the professional life of performing artists - particularly for those who did not have the opportunity to acquire the dispositions specific to the artistic field in their socialization. At this time of professional transition, 
Cette période de transition professionnelle, qui sépare les premières formulations d'un désir de vivre d'une pratique artistique de l'installation dans une forme plus ou moins stable d'intégration professionnelle, voit un certain nombre d'aspirations se heurter à la réalité du fonctionnement de l'espace professionnel du spectacle. La réduction des espérances subjectives apparaît alors comme un passage quasi obligé de l'entrée en carrière des artistes ordinaires.

\section{De la vocation aux premiers pas dans le métier}

Si les artistes ordinaires se caractérisent dans l'ensemble par une entrée dans la pratique relativement tardive et rarement orientée vers une finalité professionnelle, le récit qu'ils font de leur trajectoire n'échappe pas à la logique de la prédestination. Le registre de la vocation, qui témoigne à la fois de la constitution des métiers du spectacle en « métier à vocation " et de l'adhésion des artistes à cette croyance (Sapiro 2007), est en effet le dénominateur commun des récits biographiques suscités par la méthode de l'entretien. Les prédispositions à « se sentir prédestiné » étant fortement liées à des socialisations artistiques développées dès le plus jeune âge, certaines différences se font jour. Les artistes ordinaires issus de milieux plus favorisés évoquent plus souvent le souvenir d'un goût développé très jeune pour leur art (« tout petit déjà »), et font plus fréquemment état d'un talent précoce remarquable (et remarqué). C'est le cas de la plupart des praticiens des musiques savantes (Coulangeon 2004), des danseurs et surtout des danseuses (Sorignet 2010) qui ont commencé tôt l'apprentissage de leur art, dans des institutions de formation sélectionnées avec soin par leur famille, et qui between the initial formulations of the desire to make a living from their art and settling into a more or less stable form of professional integration, a number of aspirations come up against the actual functioning of the professional space of performing arts. The reduction of subjective expectations is therefore a virtually obligatory crossing point in the career entry of ordinary artists.

\section{From vocation to early career steps}

While as a rule ordinary artists begin to practise their art fairly late and rarely with professional ambitions, the biographical narratives elicited from them in interviews all share the language of vocation. This reflects both the construction of occupations in the performing arts as vocational occupations and the artists' adherence to this belief. As predispositions to feeling a sense of predestination are strongly correlated with artistic socialization at a very young age, some differences come to light. Ordinary artists from more privileged social backgrounds more frequently report having developed a taste for their art at a tender age ('ever since I was small') and being preternaturally and remarkably gifted as children. This is the case for most highbrow music practitioners (Coulangeon 2004) and dancers, especially women (Sorignet 2010), who began to learn their art early in training institutions that were carefully picked by their families, and who were able to project themselves into this possible destiny at quite a young age as a result. Conversely, lowbrow music practitioners, who more frequently comefrom less advantaged backgrounds - although still a minority (Coulangeon 2004)-more often begin playing 
donc ont pu se projeter très jeunes dans ce destin possible. À l'inverse, les praticiens des musiques populaires, plus souvent issus de milieux modestes - bien que toujours de manière minoritaire (Coulangeon 2004), débutent plus fréquemment à l'adolescence, dans le cadre de sociabilités amicales et hors des cadres institutionnels. Mais cette entrée plus tardive dans la pratique n'empêche pas la reconstitution d'une logique de prédestination : l'évocation d'une « révélation » provoquée par un spectacle vu pendant l'enfance, récurrente chez les comédiens (Menger 1997) et les artistes de cirque (Garcia 2011), vient donner rétrospectivement du sens à un engagement personnel qui s'est produit bien des années plus tard. Quand Gaston, 56 ans, raconte comment il est devenu comédien, il commence par mentionner le souvenir vague d'une pièce de Marcel Pagnol jouée à l'école primaire. Pourtant, né de parents ouvriers dans une petite ville de province, sans formation ni expérience artistiques en dehors de sa participation à un groupe de rock familial, il n'a débuté son activité de clown de rue qu'à 40 ans, poussé par le désir de « (s')échapper » d'une carrière professionnelle difficile qui l'a conduit à exercer de nombreux métiers d'exécution dans l'industrie et les services. L'admiration de « vedettes » est un autre élément présenté comme déclencheur de la vocation par de nombreux artistes ordinaires. Hervé, 40 ans, fils d'ouvriers d'une petite ville industrielle, explique avoir appris à jouer de la batterie lorsqu'il était adolescent, en mimant le batteur de son groupe fétiche (Lars Ulrich, du groupe heavy metal étasunien Metallica), reproduisant fidèlement sur des casseroles empruntées à sa mère (et plus tard sur une vraie batterie au sein d'un groupe d'amis) toutes les chansons de leur premier album. Les vocations sont en partie nourries during adolescence with friends, outside of any institutional framework. Despite their later introduction to the practice, they still reconstruct it in terms of predestination: often, the evocation of a "revelation" upon seeing a performance during childhood, especially for actors (Menger 1997) and circus performers (Garcia 2011), gives meaning retrospectively to a personal commitment that happened years later. Gaston, 56, the son of blue-collar workers in a provincial small town, had no artistic training or experience outside of playing in a family rock group. When he relates how he became a comedian, he starts out by mentioning a vague recollection of watching a Marcel Pagnol play at his primary school. Yet he only began working as a street clown at 40 , motivated by the desire to "escape" a struggling professional career in which he held a wide variety of menial jobs in the industrial and service sectors. Many ordinary artists also report being inspired in their vocation by "stars" they admired. Forty-year-old Hervé, the son of blue-collar workers in a small industrial town, explains that he learned to play the drums as a teenager by imitating the drummer of his favourite band (Lars Ulrich of the American heavy metal group Metallica), faithfully reproducing all of the songs of their first album on pans borrowed from his mother (and later on a real drum kit in a band with his friends). Vocations are partly nurtured by media representations of the artist's life-both as an unattainable dream and as the only way of envisioning the job. In the words of 33-year-old Albertine, "When I was a kid, I didn't know there was such a thing as non-famous actors, I thought either you were a star or you were nothing at all!" After obtaining a bachelor's degree in the performing arts to "reassure" her mother, a schoolteacher, she left university and joined a small semi- 
par les représentations médiatiques de la vie d'artiste qui forment indissociablement un rêve inaccessible et l'unique manière de concevoir le métier. Comme le dit Albertine, 33 ans : «quand j'étais piotte, je savais pas qu'il y avait des comédiens non connus, je pensais qu'on était soit star soit rien du tout ! ». Après une licence d'arts du spectacle, passée «pour rassurer (s)a mère institutrice », elle quitte l'université et rejoint une petite troupe semi-professionnelle pour essayer de réaliser son rêve : devenir comédienne, "comme les stars de cinéma » et, plus encore, de théâtre qu'elle voyait à la

télévision ${ }^{6}$

Les croyances en l'idéologie du don et de la prédestination, en l'inévitable consécration des talentueux, qui constituent l'illusio nécessaire à l'appartenance au champ artistique, sont d'autant plus fortes qu'elles se trouvent associées à une très faible connaissance des réalités concrètes du métier. Les premiers pas dans la carrière sont donc l'occasion d'une confrontation parfois brutale entre les représentations fantasmées de la vie d'artiste et les faits qui composent la vie quotidienne des professionnels du spectacle. Loin de la « rationalité professionnelle » des héritiers et de leur famille (Lehmann 2002) qui anticipent, du choix de l'instrument à celui de l'école, les débouchés possibles de l'apprentissage d'un art, les aspirants moins bien dotés s'exposent à des difficultés en termes d'intégration et de reconnaissance professionnelle dont ils mésestiment souvent l'importance.

6 La famille était spectatrice régulière de l'émission populaire $A u$ théâtre $c e$ soir, diffusée en France entre 1966 et 1986, retransmettant des comédies jouées dans des théâtres privés parisiens (Goetschel 2004). professional company to try to achieve her dream of being an actor, "like movie stars," and, in particular, the theatre actors she had seen on television 6 .

Beliefs in the ideology of the gift and of predestination, in the inevitable consecration of the talented, constitute an illusio that is necessary in order to belong in the artistic field. These beliefs are particularly strong when combined with a very low level of knowledge of concrete job realities. Hence, the first career steps are the occasion of a sometimes-brutal confrontation between fantasized representations of the artist's life and the mundane facts of everyday life for professionals in the performing arts. Far from the "professional rationality" of the inheritors and their families (Lehmann 2002), who anticipate the possible outcomes of learning an art at each step of the way, from the choice of instrument to the choice of school, the less endowed aspirants are exposed to setbacks because they often underestimate the importance of professional integration and recognition.

6 The family regularly watched the popular show $\mathrm{Au}$ theâtre ce soir, which between 1966 and 1986 broadcast comedies played in private Parisian theatres to French television audiences (Goetschel 2004). 
La première difficulté réside dans l'apprentissage des règles de l'intermittence. Si dans le milieu du théâtre, la socialisation aux conditions de travail et d'emploi est progressive, passant à la fois par l'école (Katz 2007) et par la troupe (Proust 2003), il n'est pas rare que des musiciens découvrent l'existence même de ces règles à l'occasion de leur premier contrat, comme en témoigne ce guitariste.

"Nous avec le groupe on a toujours été un peu à l'arrache... on faisait de la zik, on vivait du $\mathrm{RMI}^{7}$ mais on s'en foutait... ça a duré quatre ans à peu près... Et puis à un moment, on s'est dit que c'était quand même con parce qu'on commençait à jouer pas mal et donc on a décidé de passer pro, de se faire payer pour jouer... Mais on n'y connaissait vraiment que dalle ! Je me rappelle, la première fois qu'on a démarché un bar, on a dit au gars qu'on voulait un cachet, et là le gars il dit "oui, pas de problème, on va passer par le GUSO ${ }^{8}$ "... eh ben nous, on ne savait même pas ce que c'était ! Limite j'allais lui demander "Ah ouais, et c'est qui ce GUSO ?" L'air con! [Rires.] Ben ouais, jusque-là on jouait gratos dans des bars ou des petits restos, des fêtes de village, des fois à la limite on nous filait la pièce au black, souvent on avait juste le repas et les consos donc, nous, les histoires de GUSO, d'intermittence, d'annexes et tout ça, c'était loin ! » (Tom, 31 ans, guitariste intermittent, père ouvrier et mère au chômage.)

7 Revenu minimum d'nsertion (remplacé en 2009 par le revenu de solidarité active).

8 Guichet unique du spectacle occasionnel : dispositif administratif facilitant pour les employeurs occasionnels (particuliers, commerçants, collectivités) les démarches d'embauche d'un artiste ou d'un technicien et le paiement des cotisations sociales.
The first difficulty lies in learning the rules of the employment status of French performing artists-intermittents du spectacle. While in theatre, socialization to working and employment is progressive-taking place both in school (Katz 2007) and in companies (Proust 2003); it is relatively common for musicians to find out about the very existence of these rules upon securing their first contract-a guitar player illustrates this:

"With the band we were always sort of winging it... We played our tunes, lived off the RMI7 but we didn't give a shit... That went on for four years, give or take ... And then at some point we realized it was daft, since we were starting to play quite well, so we decided to become pros, to get paid to play... But we knew absolutely nada about that stuff! I remember, the first time we went to a bar, we told the bloke we wanted a fee, and the bloke went, 'OK, sure, we'll go through $\mathrm{GUSO}^{8}$ '... and we didn't even know what that was! I was nearly going to ask him, 'Oh yeah, and who's that GUSO?' We looked daft! [Laughs.] So yeah, before that we'd play for free in bars or small restaurants, village parties, sometimes they'd slip us a coin, often we just got dinner and drinks on the house, so all that stuff with GUSO, intermittence, annexes supplementary income, and all that, we weren't exactly there yet!" (Tom, 31 years old, guitar player with intermittent status; blue-collar worker father and mother unemployed.)

7 Revenu minimum d'insertion, the former minimum benefit replaced in 2009 by the Revenu de solidarité activité (RSA).

8 GUSO is the "Guichet unique du spectacle occasionnel," which is a one-stop administrative shop for performers, facilitating the process of hiring an artist or technician and the payment of social security for occasional employers (private individuals, business owners, local authorities, etc.). 
Au cours des premières années de sa carrière, Tom a dû acquérir la maitrise pratique des multiples règles qui organisent l'activité artistique et qui font le « métier d'intermittent 》 (Sinigaglia 2007), marquant la transition difficile entre une activité en amateur et le statut de professionnel. Beaucoup découvrent également que le travail artistique comporte un volume important de tâches administratives : comptabilité personnelle, déclarations aux organismes gérant les cotisations sociales mais aussi, pour certains d'entre eux, rédaction de dossiers de demandes de subventions, rencontres d'éventuels partenaires institutionnels, communication avant pendant et après le projet, etc. Autant d'activités qui semblent bien éloignées de la figure romantique de l'artiste, tout entier consacré à son art.

La dernière difficulté, et non des moindres pour les artistes qui rêvent de marcher sur les traces de leurs idoles, réside dans l'interaction avec le public. Les premiers spectacles des amateurs, s'ils peuvent se dérouler dans des conditions quasi professionnelles (une scène, des lumières et une sonorisation de qualité) se produisent souvent devant un public au moins en partie conquis d'avance, composé d'amis, voire de membres de la famille, et certains artistes font même l'expérience de formes locales de reconnaissance (Morinière 2007). Les premiers pas de professionnels, notamment lorsqu'ils ne se font pas « à domicile », pour reprendre la métaphore sportive utilisée par un musicien, peuvent occasionner des expériences bien différentes : les salles presque vides, un public peu attentif, des applaudissements erratiques, des départs prématurés plus ou moins discrets, etc. Tranchant parfois radicalement avec les premières expériences vécues
During the first years of his career, Tom had to acquire a practical mastery of the multiple rules governing artistic activity and constituting the "intermittent occupation" (Sinigaglia 2007), a staple of the difficult transition between amateur practice and professional status. Many discover that artistic work involves a great deal of administrative tasks: keeping personal accounts, filing declarations on social contributions to the relevant organizations, and in some cases writing applications for subsidies, meeting institutional partners, handling communication before, during and after projects, etc. - all tasks that seem far removed from the romantic figure of the artist who devotes their entire life to art.

Finally, especially for those who aspire to walk in the footsteps of their idols, the third main challenge faced by these artists is to manage interactions with the public. The first performances of amateurs may take place in near-professional conditions (on a stage with good lights and sound), but their audiences often comprise friends and family members who do not need winning over; some artists even experience local forms of recognition (Morinière 2007). When artists take their first steps away from the "home turf," to use a sports metaphor employed by a musician, their experiences can be very different: nearly empty venues, inattentive audiences, scattered applause, people leaving more or less discretely during the performance, etc. These at times radical departures from earlier experiences of the stage can lead artists to reconsider their professional and personal lives. Thirty-yearold Boris, a guitar and bass player in several bands, relates 
de la scène, ces épreuves peuvent conduire les artistes à des remises en cause professionnelles et personnelles. Boris, 30 ans, guitariste et bassiste dans plusieurs formations, s'arrête un long moment sur une anecdote. Alors qu'il se produisait avec son groupe de reprises pop-rock dans un casino, jouant des titres qu'il n'apprécie pas devant un public qui se désintéresse visiblement de la prestation, il prend soudainement et douloureusement conscience de sa place :

«Une fois ça m'a fait ça, je jouais de la basse avec le groupe d'animation dans un casino... j'ai carrément fait un blanc, je me suis arrêté, les zicos m'ont regardé, ils ont pas compris, ils m'ont laissé comme ça et, à la fin de la chanson, ils ont fait une pause... et moi je me disais, qu'est-ce que je fous là ?, j'ai l'impression d'être à l'usine, je me fais chier, je joue de la merde ! Enfin voilà, quoi... j'assumais pas : je faisais du bal... je disais à mes collègues "prenez un autre mec", moi j'en peux plus, j'arrête ! C'est terrible ça, tu sais que personne t'écoute... d'ailleurs, des fois, on fait des tests : une fois, j'ai joué la ligne de basse d'un morceau de Lou Reed sur un morceau de Marley, n'imp', eh ben personne ne remarque ! Une fois on a même chanté les paroles de Walk This Way sur la musique de On ira tous au paradis, un truc qui devait être horrible en façade, eh ben c'est passé tout seul, comme si de rien... c'est déprimant en fait. " (Boris, 30 ans, guitariste intermittent, père éducateur et mère infirmière.)

Avant de devenir intermittent du spectacle, Boris a travaillé comme aide soignant contractuel dans un hôpital public. Son groupe de rock amateur a rencontré un certain succès dans la région, ce qui a incité une partie des musiciens à quitter leurs emplois et tenter l'aventure d'une carrière professionnelle. a long anecdote about performing in a casino with his band, playing pop-rock covers he did not like to an audience that clearly did not care-a time when he suddenly and painfully became aware of his place:

"This happened to me once, I was playing bass in a casino with the party band... I drew a complete blank, I just stopped. The guys stared at me, they didn't get it, they left me like that and at the end of the song they took a break... and there I was asking myself, what the fuck am I doing here, I feel like I'm punching the clock, I'm bored as hell, and I'm playing shit! You know... I couldn't get into that: I was just playing at functions. I'd tell the others, 'listen, hire some other guy. I can't take it anymore, I quit! It's dreadful. You know nobody's listening.' [...] Actually, sometimes we tested them: once I played a Lou Reed bassline on a Bob Marley tune, rubbishwell, no one notices! Once we even sang the lyrics to Walk This Way over the music of [Michel Polnareff's] On ira tous au paradis, which was supposed to sound horrible, and it went like a breeze, like nothing ... It's depressing, actually. (Boris, 30 years old, guitar player with intermittent status; father social educator and mother a nurse.)

Before becoming an intermittent, Boris worked as a contracted nursing auxiliary at a public hospital. As his amateur rock band became fairly successful locally, some of the musicians left their jobs to pursue professional careers. But the group turned out to be insufficiently active to generate regular income. 
Mais l'activité du groupe se révèle insuffisante pour en tirer des revenus réguliers. Au bout de quelques mois, chacun est pris par ses multiples activités annexes et le groupe se sépare. Contrairement à d'autres musiciens, Boris a pu bénéficier de la solidarité d'amis intermittents qui l'ont aidé à obtenir suffisamment d'engagements pour conserver des droits ouverts à l'indemnisation du chômage. Mais la carrière qu'il vit est bien différente de celle qu'il imaginait. Face à ces épreuves, aux insatisfactions voire aux frustrations générées par le décalage entre les espérances subjectives et la réalité objective, de nombreux artistes sont découragés et font le choix de ce que Catherine Paradeise nomme « l'abandon réaliste » (Paradeise 1998 : 34). Ceux qui restent, généralement parce qu'ils disposent des ressources et des relations leur permettant de retirer suffisamment de gratifications matérielles et/ou symboliques de leurs activités, doivent néanmoins revoir à la baisse leurs aspirations.

\section{Deuil de la consécration et mise à distance} des « rêves de môme »

L'entrée dans la carrière artistique, que l'on soit créateur et/ou interprète, prend donc la forme d'une succession d'épreuves : participer à des tremplins pour jeunes talents, briguer des prix, solliciter diverses aides à la création, obtenir suffisamment d'engagements pour accéder au régime d'indemnisation des intermittents, etc. Chacune de ces épreuves permet aux artistes de prendre plus ou moins conscience de la place qu'ils occupent dans l'espace professionnel et de leur avenir probable. Bien sûr, ces épreuves ne départagent pas des aspirants égaux au départ. Au contraire, leurs issues
After a few months, everyone founds themselves busy doing their multiple jobs on the side, and the band split up. Unlike other musicians, Boris received the assistance of intermittent friends who helped him get enough jobs to remain eligible for unemployment allowance. But his career is far from the life he imagined.

In the face of such challenges, of the dissatisfaction and frustration created by the gap between subjective aspirations and objective reality, many artists become discouraged and opt for what Catherine Paradeise calls "realistic disengagement" (Paradeise 1998: 34). Those who go on do so generally because they have enough resources and relations to derive sufficient material and/or symbolic gratification from their activity. Yet they have to scale down their ambitions.

\section{Giving up on consecration and childhood dreams}

Entry into an artistic career, for creators and performers alike, is a succession of trials: they have to participate in showcases for young talent, apply for awards and various subsidies, secure enough jobs to have access to unemployment allowance, etc. Each of these trials allows artists to gain a degree of awareness of their place in the professional space and of their likely future. Of course, whatever selection they operate is not between initially equal aspirants. Their outcomes unveil inequalities that are largely the result of divergent social trajectories. The best endowed aspirants, trained in 
rendent visibles des inégalités qui sont en grande partie le produit de trajectoires sociales différenciées. Les mieux dotés, formés dans des écoles prestigieuses et disposant d'un capital social important, parviennent à tirer assez tôt leur épingle du jeu. C'est le cas par exemple de Camille, 30 ans (père médecin et mère professeure), diplômée du Conservatoire national supérieur d'arts dramatiques. La compagnie de théâtre contemporain qu'elle a créée avec son conjoint pendant ses études en Arts du spectacle a bénéficié dès sa création d'une forme de résidence permanente en théâtre universitaire puis, à son retour du Conservatoire, obtient régulièrement des aides publiques qui permettent de stabiliser la compagnie devenue professionnelle. Ces signes d'une reconnaissance croissante laissent entrevoir un avenir professionnel plutôt prometteur. Pour les autres, moins bien dotés, les échecs répétés dessinent un champ des possibles qui se réduit et rend de plus en plus incongru l'entretien de hautes aspirations. C'est le cas de Michael, bassiste, 29 ans. Bien que fils d'un musicien d'orchestre national (lui même fils d'ouvrier), dernier d'une fratrie de cinq enfants, il peut difficilement être considéré comme un héritier : il a commencé tardivement l'apprentissage de son instrument, au sein d'une petite formation rock montée avec quelques amis, et est sorti du système scolaire sans diplôme pour tenter sa chance dans la musique. Fan de Jaco Pastorius et de Marcus Miller (bassistes funk de renommée mondiale), il s'imaginait, à terme, accompagner des artistes dans de grandes tournées internationales. Mais devant les difficultés rencontrées ne serait-ce que pour trouver des engagements dans sa petite ville de province, il révise à la baisse ses ambitions («Maintenant je sais que je ne jouerai jamais à l'Olympia! prestigious schools and armed with large amounts of social capital, often get a fairly early breakthrough. An example of this is provided by thirty-year-old Camille (whose father is a doctor and mother a teacher), who graduated from the national conservatory for the dramatic arts. The company she created with her boyfriend when she was studying performing arts at university was immediately granted a permanent residency at the university theatre; since graduating from the conservatory, she has been regularly receiving public subsidies that allow her to balance the budget of the now professional company. These signs of growing recognition suggest a rather promising professional future for her. For those less well off, repeated failures reduce the field of possibles and make having high aspirations somewhat incongruous. This is to the case for 29 -year-old bass player Michael. Although he is the youngest of the five children of a musician in a national orchestra (who was himself the son of a blue-collar worker), he can hardly be considered an inheritor: he began to learn his instrument late, in a small rock band with a few friends, and left the education system without a degree to try his luck with music. A fan of world-famous funk bass players Jaco Pastorius and Marcus Miller, he pictured himself eventually embarking on large international tours. But in light of how difficult it has been for him even to find jobs in his provincial small town, he has curbed his ambitions ("now I know l'll never get to play the Olympia! [A prestigious Parisian venue.] Oh well.") and makes a virtue of necessity to the extent of manifesting a "form of love of necessity, amor fati" (Bourdieu 2000: 146): "I've been doing caf-conc' [coffeehouse gigs], giving some lessons, ultimately I'm still doing what I love." 
C'est comme ça. ») et fait de nécessité vertu, au point de manifester « une forme d'amour de la nécessité, d'amor fati » (Bourdieu 2003 : 206) : « Là, je fais du caf-conc', je donne un peu de cours, je fais quand même ce que j'aime au final. »

Le rêve de la célébrité se trouve alors assimilé au cours des entretiens à «l'inconscience » de l'artiste débutant : inconscience de la grandeur relative de son «talent », méconnaissance du fonctionnement du milieu professionnel, ignorance des mécanismes qui permettent d'accéder à la notoriété. Les figures les plus emblématiques de la consécration, celles de la vedette de variétés ou de la star de cinéma, sont fréquemment mises à distance, renvoyées du côté du futile et du ringard, dans un discours qui prend la forme d'une dénonciation des « stars en boite " ou « à la chaîne » fabriquées par l'industrie de l'entertainment. L'entrée en carrière semble donc imposer aux artistes ordinaires de se défaire, le plus rapidement possible, de ces illusions. C'est ce que montre par exemple l'entretien avec Loïc, auteur-compositeur-interprète de 35 ans. Après des études supérieures en marketing et une courte expérience dans le secteur du commerce, il se lance à 25 ans dans la musique, qu'il pratique en amateur depuis quelques années, avec un projet ferme et déterminé : devenir un chanteur « populaire», à la fois au sens de la «pop » anglophone (ses premières idoles sont des stars de pop rock, comme Radiohead) et de

la variété française.

« La célébrité, c'est plutôt un rêve de début de carrière, parce c'est un peu l'inconscience du début : "Moi j'vais y arriver, je suis bon !"... mais c'est vrai que t'as toujours
In interviews, early dreams of stardom are retrospectively attributed to the "lack of awareness" of beginners as regards the relative worth of their "talent," the way the professional art world works, and of the mechanisms in place to access fame. The most emblematic figures of consecration-celebrities of the pop and film world-are frequently dismissed as trivial or behind the times in discourse that denounces "assemblyline" pop stars "manufactured" by the entertainment industry. Starting a career therefore appears to require ordinary artists to rid themselves of such illusions as soon as possible. This is evidenced by an interview with thirty-year-old songwriter Loïc. After a degree in marketing and a short stint in business, he got into music at the age of 25 with a clear goal in mindthat of becoming a singer and blending the sensibilities of UK and US pop-rock groups such as his first idols, Radiohead, with mainstream French pop.

"Fame is a dream that you tend to have when you begin your career, because you're sort of clueless at first, you go 'I'm going to make it, 'cos I'm good!'... But you always have a 
un manque de reconnaissance... tu sens qu'il te manque quelque chose... Au début, j'avais une vision de la réussite très claire : jouer devant 500 personnes et qu'ils m'aiment ! [Rires.] [...] Après y'a une image idéale comme ça du musicien qui est de faire des grosses tournées dans des salles pleines... comme des Zazie, Calogero [des stars de la variété française], tout ça... mais bon, après, chacun réduit ses aspirations [...] C'est bien d'avoir un rêve mais, une fois que t'as accepté que t'auras pas de villa sur la côte d'azur, ça va mieux quand même ! [Rires.] 》 (Loïc, 35 ans, auteur-compositeur-interprète intermittent, parents employés.)

Malgré une courte mais intense expérience de la notoriété (il est sélectionné pour le tremplin d'un grand festival national puis atteint la finale d'une célèbre émission de télé-crochet), rapidement suivie d'un retour à l'anonymat, ces premières expériences l'ont amené à faire subir à son rêve une adaptation « réaliste » (Bourdieu 1974). Mais les épreuves ne sont pas les seuls éléments qui amènent les artistes ordinaires à prendre conscience de leur place et à redéfinir leurs attentes. Si le cercle des pairs fonctionne comme « un club d'admiration et de réassurance mutuelles " (Mauger 2006b : 243) aidant à surmonter les phases de doute et de remise en cause, il permet aussi aux artistes ordinaires de renforcer leur « sens des limites " (Zunigo 2008), à ne pas s'épuiser en visant des objectifs hors d'atteinte. Mais ce processus, qui n'est pas nécessairement conscient ou volontaire, est difficile à analyser parce «qu'il peut y avoir adhésion à un ordre sans que personne n'ait voulu adhérer » (Bourdieu 2015). Souvent d'ailleurs, les croyances persistent même une fois que la nécessité est incorporée, comme le montrent ces deux extraits d'entretien. lack of recognition... You feel you're missing something... At first I had a very clear vision of success: playing in front of 500 people who loved me! [Laughs]... Well the thing is, you've got this ideal image of musicians doing these big tours in sold-out venues... like Zazie, Calogero [French pop stars], all that... But then everyone reduces their aspirations... It's fine to have a dream, but once you've accepted you're not going to have a villa on the Riviera, well now you're better off! [Laughs.]" (Loïc, 35 years old, singer-songwriter with intermittent status, both parents employees.)

Despite a short but intense burst of recognition (he was selected to participate in the showcase for a prominent national festival, then reached the finals of a well-known TV talent show), quickly followed by a return to anonymity, these early experiences caused him to make "realistic" (Bourdieu 1974) adjustments to his dreams. Yet early-career trials are not the only factors which lead ordinary artists to gain awareness of their place and redefine their expectations. The peer circle functions as a "club of mutual admiration and reassurance" (Mauger 2006b: 243) that helps overcome moments of doubt, but it also allows ordinary artists to reinforce their "sense of limitations" (Zunigo 2008), to avoid exhausting themselves by pursuing exceedingly lofty goals. Yet this process, which is not necessarily deliberate or conscious, is difficult to analyse because "adhesion to an order may exist without anyone having sought to adhere" (Bourdieu 2015). Often, beliefs endure even when necessity has been internalized, as in the following two cases: 
"Parce que nous les artistes, de quoi on rêve c'est d'être médiatique : être reconnu... qui est la pire fiction, ou le pire désastre qui puisse arriver [...] le premier deuil à faire dans la musique, c'est vraiment la reconnaissance ! II faut intérioriser le fait qu'on sera jamais compris, reconnus, traités de tous les noms, ou encensés alors qu'on pensera que c'est de la merde... [...] Mais en même temps, je ne vois pas comment on peut faire de la musique, en public, sans un minimum de reconnaissance... " (Victor, 31 ans, percussionniste, bénéficiaire du RSA, père cadre intermédiaire et mère employée.)

«Moi mon but dans la vie c'est pas d'être célèbre, c'est d'en vivre... pour rester honnête on cherche tous un peu de reconnaissance, si demain notre projet marche plus que de raison tant mieux... mais si ça marche comme aujourd'hui donc ça tourne, je fais des dates, je rencontre plein de gens, je fais de jolies petites salles, ça me va. » (Aurore, 30 ans, musicienne et comédienne intermittente, parents instituteurs.)

En effet, l'ajustement des espérances n'implique pas (ou ne permet pas) de rompre avec l'illusio, la croyance dans le jeu et dans sa capacité à jouer le jeu (Bourdieu 2003). Au contraire, elle se trouve même renforcée. Par exemple, si les formes les plus médiatiques de consécration sont décriées, les exemples de réussite «plus underground », « moins commerciaux » constituent pour beaucoup des modèles acceptables. Plusieurs musiciens de rock ont ainsi cité l'exemple de Thom Yorke, leader charismatique du groupe Radiohead, dont le mérite serait précisément de n'avoir « pas cherché le succès »... mais de l'avoir trouvé quand même ${ }^{9}$. S'il est très improbable que des artistes ordinaires, a

$9 \quad$ Une analyse sociologique de la trajectoire du leader de Radiohead remettrait probablement en cause cette lecture romantique du succès de la rock star.
"Us artists, what we dream of is getting in the media: being recognized... It's the worst fiction, or the worst disaster that can happen... In music, the first thing you have to let go of, really, is recognition! You have to internalize the fact that you'll never be understood, recognized, called all kinds of names, or acclaimed-people will think you're shit... But then again, I can't see how you can play music in public without the slightest bit of recognition." (Victor, 31 years old, percussionist, RSA recipient, father mid-level manager and mother employee.)

"As far as I'm concerned, my goal in life isn't to be famous, it's to make a living from it... To be honest, we're all looking for some recognition, if it happens that our work starts to do better than we can reasonably expect we'll accept it gladly... But if it continues to go like it's going now, it's alright, I do gigs, I meet a lot of people, I play nice little venues, it suits me fine." (Aurore, 30 years old, musician and actress with intermittent status, both parents schoolteachers.)

Indeed, adjusting one's expectations does not require (or allow) a break with the illusio, the belief in the game, and in one's ability to play the game (Bourdieu 2000) - on the contrary, it makes it even stronger. For instance, even if the most publicized forms of consecration are decried, examples of "more underground," "less commercial" success are acceptable models to many. Several rock musicians mention Radiohead frontman Thom Yorke, whose merit, they claim, is precisely that he did not "seek out success," but found it anyway ${ }^{9}$. While it is highly unlikely that ordinary artists, especially those living in small towns, could experience

9 A sociological analysis of Thom Yorke's career would probably challenge this romantic view of the rock star's success. 
fortiori installés en province, connaissent un destin similaire, rien ne permet d'affirmer que cette probabilité est nulle pour chaque cas particulier. Ces modèles, aussi fantasmés soient-ils, permettent donc de conserver la croyance qu'en faisant simplement son travail avec application et sincérité, la consécration pourrait finir par arriver. L'expression «si demain notre projet marche plus que de raison » utilisée par Aurore est significative : elle dit savoir (« de raison ») que ses chances objectives d'être consacrée sont infimes, mais elle conserve la croyance («si demain ») qu'il pourrait en être autrement. Tout ce travail sur les aspirations, plus ou moins conscient, à la fois individuel et collectif, mais toujours déterminé par les conditions sociales de production de I'habitus des agents concernés, semble donc paradoxalement renforcer la croyance partagée dans la doxa du champ artistique : l'innéité du don, le hasard de la découverte et de

la consécration du talent.

\section{Trouver sa place : l'incorporation de la domination}

Si le deuil des premières aspirations est un passage quasi obligé de l'entrée en carrière des artistes ordinaires, il ne saurait y avoir que du vide à la place du « rêve » qui formait le socle de la vocation. Les « espérances de gain » (Menger 1997), matériels ou symboliques, peuvent certes expliquer en partie l'engagement puis le maintien dans la carrière, mais encore faut-il que ces espérances soient crédibles aux yeux de ceux qui les portent, c'est-à-dire que « l'agent dispose de chances pour gagner qui ne soient ni nulles (à tous les coups l'on perd) ni totales (à tous les coups l'on gagne), ou, a similar destiny, there is no evidence to say they have no chance whatsoever. Even fantasized, these models allow artists to continue believing that if they simply keep doing their job earnestly and sincerely, consecration might one day come. Aurore's phrase "if our work suddenly started to do better than we could reasonably expect" is significant here: she claims to know ("reasonably") that her objective chances of attaining consecration are very small, but she still believes ("if our work suddenly started") that things could go differently. All this work on aspirations, which is conscious to varying degrees and both individual and collective, but is always determined by the social conditions of the production of habitus for the agents concerned, appears to paradoxically reinforce the shared belief in the doxa of the artistic field: the innateness of the gift, the randomness of discovery and the consecration of talent.

\section{Finding one's place: the internalization of domination}

While giving up one's initial aspirations is a staple of career entry for ordinary artists, the void left by the "dream" in which the vocation used to be rooted must be filled. "Hopes of [material or symbolic] gain" (Menger 1997) can of course go some way towards explaining that artists begin and continue careers, but these hopes have to be credible in the eyes of those who have them-meaning that "the agent has to have chances of winning which are neither nil (losing on every throw) nor total (winning on every throw). In other words, nothing must be absolutely sure, but not everything must be 
autrement dit, que rien ne soit absolument sûr sans que tout soit possible pour autant » (Bourdieu 2003 : 308-309). Si l'on peut admettre que « l'épreuve de l'incertitude [sur le cours de l'activité et son résultat] donne au travail créateur [...] ses satisfactions les plus hautes » (Menger 2009), l'échec répété face à ces épreuves est une source tout aussi importante d'insatisfaction et de souffrance morale. L'enquête montre que c'est plutôt dans l'ajustement entre les dispositions personnelles (économiques, culturelles, esthétiques) et les opportunités offertes par la structure d'un espace (plus ou moins localisé) de pratiques artistiques professionnelles (les opportunités d'emploi disponibles dans une région, l'état de la concurrence, etc.) que l'on peut saisir les mécanismes qui, d'une part, favorisent le maintien de l'engagement dans la carrière mais aussi, d'autre part, tendent à assigner à chaque agent « sa place » dans l'espace professionnel. Pour le dire autrement, les stratégies que sont en mesure de mettre en œuvre les artistes ordinaires peuvent leur permettre de se maintenir dans le métier mais, en même temps, les confinent dans les régions dominées du champ artistique.

\section{La diversification : identité professionnelle} versus identité artistique

Si l'ajustement des aspirations repose en partie sur la maîtrise, plus ou moins objectivée, de l'espace de jeu (c'està-dire notamment la connaissance des règles du jeu, des ressources efficientes, des acteurs influents, des opportunités offertes dans un espace donné), il se manifeste également par une adaptation de la façon de jouer à la place occupée dans cet espace. En effet, la place structure les conduites possible" (Bourdieu 2000: 213). If "the trial of uncertainty [on the course and outcome of an activity] gives creative work... its greatest rewards" (Menger 2015), repeated failures are just as important a source of dissatisfaction and moral suffering. My interviews suggest that the adjustment between personal (economic, cultural, aesthetic) dispositions and the opportunities offered by the structure of local spaces of professional artistic practice of varying sizes (job opportunities, state of the competition, etc.) is a core feature of mechanisms that both facilitate career maintenance and lead each agent to be assigned "their own place" in the professional space. In other words, the strategies at the disposal of ordinary artists may allow them to pursue their careers further, but at the same time they keep them in the dominated spheres of the artistic field.

\section{Diversification: professional versus artistic identity}

The adjustment of aspirations is partly based on a degree of objectivized mastery of the space of play (including knowledge of the rules of the game, of effective resources, influential actors, and opportunities available in a given space), but it is also characterized by agents' adaptation to a way of playing with their place within this space. Indeed, place structures agents' behaviours - the game is not played 
des agents et on ne joue pas le jeu de la même manière dans les régions dominantes du champ artistique, dans lesquelles les formes de rétributions matérielles et symboliques du travail artistique et les chances d'accéder à la consécration sont objectivement plus nombreuses que dans les régions dominées où évoluent principalement les artistes ordinaires.

Pour les artistes, créateurs et/ou interprètes, qui peuvent (et se sentent autorisés à) espérer une forme de reconnaissance de leur talent, le maintien d'une certaine cohérence dans les choix artistiques apparaît primordial. Amélie, 32 ans, diplômée d'une grande école d'art dramatique, explique qu'elle ne peut se permettre d'accepter « n'importe quel rôle » ou de travailler avec " n'importe quelle compagnie ». Le soutien financier de ses parents (père avocat et mère ingénieure) la préserve des activités annexes et de la course aux cachets et l'autorise à ne sélectionner que les projets qui correspondent à son « univers artistique ». L'enjeu pour cette comédienne est clairement de "garder la face » (Goffman 1973) dans la mesure où l'occupation d'un emploi, au sens du poste de travail et du type de rôles dramatiques (Duvignaud 1965), marque l'identité d'un interprète, la manière dont il se perçoit et est perçu par l'ensemble des acteurs de son monde professionnel. Cette stratégie, rendue possible par l'importance de ses capitaux culturels et économiques, lui permet de préserver ses chances d'accéder à la consécration.

À l'inverse, les artistes plus faiblement dotés en ressources efficientes et dans des situations professionnelles et sociales plus précaires, sont amenés à jouer une autre stratégie : similarly in the dominant spheres of the artistic field, where material and symbolic rewards for artistic work and the chances of reaching consecration are obviously greater, as in its dominated spheres, which is where most ordinary artists are active.

For creators and performers who can hope for some form of recognition of their talent (and feel allowed to entertain this hope), remaining somewhat consistent in their artistic choices is key. Thirty-two-year-old Amélie, a graduate of top school for the dramatic arts, explains that she cannot accept "just any role" or work with "any company." Thanks to her parents' financial support (her father is a lawyer and her mother an engineer), she does not have to spend time on other work or constantly look for paid jobs; she can afford to select only projects that fit her "artistic universe." What is at stake for Amélie is clearly to "save face" (Goffman 1956) insofar as being well employed, both in the sense of having work and of having roles that suit her (Duvignaud 1965), is a defining feature of a performer's identity - of the way they perceive themselves and are perceived by other actors in their professional world. This strategy is made possible by her high levels of cultural and economic capital, and allows her to preserve the hope of reaching consecration.

Conversely, artists who have the least effective resources and who are in more precarious professional and social situations 
celle de la diversification ${ }^{10}$. À un premier niveau, celle-ci ne constitue pas nécessairement une entrave à l'impératif de « singularité » de l'artiste (Heinich 2005) et n'implique pas l'abandon de toute aspiration à la reconnaissance. Confrontés à la difficulté de vendre et de faire tourner leur spectacle, certains artistes font le choix d'adapter sa forme, et plus précisément de réduire le nombre d'artistes sur scène, au budget du lieu qui les accueille. Une troupe de théâtre installée en province met ainsi en avant sa capacité d'adaptation en allant jusqu'à se nommer « TGV EST », la «Troupe à Géométrie Variable Exerçant Sans Tabou ». Cette stratégie est mise en œuvre par de nombreux musiciens. Fabrice, 24 ans, musicien auto-entrepreneur, considère que les «petites salles » n'ont plus les moyens de rémunérer correctement les groupes au-delà d'un certain nombre de musiciens et estime qu'il « faut savoir aussi les faire bouger, évoluer en fonction de comment ça peut tourner ». Paolo, 40 ans, qui vient de bénéficier d'une résidence de création pour finaliser son nouvel album et préparer la tournée, livre le même témoignage désabusé :

« Là, avec le nouveau projet, on est six, c'est comme ça qu'on a créé le spectacle pendant les résidences, et c'est comme ça qu'on a enregistré l'album. II faudrait que j'aille trouver plein de dates pour faire connaitre le projet,

10 II n'est pas question ici de la multiactivité nécessaire aux artistes ordinaires pour parvenir à vivre de leur art et qui consiste à exercer des emplois complémentaires à l'intérieur ou à l'extérieur des mondes de l'art (Bureau, Perrenoud, Shapiro 2009) mais bien de la diversification des projets dans des registres esthético-artistiques potentiellement différents. resort to another strategy, namely diversification ${ }^{10}$. On one level, this strategy does not necessarily constitute a hindrance to the imperative of being a "singular" artist (Heinich 2005) and does not require all aspirations of recognition to be abandoned. Faced with the difficulty of selling and touring their shows, some artists decide to adapt their form to the budget of the venues where they play, in particular by reducing the number of artists on stage. A provincial theatre company went so far as to emphasize this adaptability by calling themselves "TGV EST"- the name of the high-speed train from Strasbourg to Paris, except their acronym stands for Troupe à Géométrie Variable Exerçant Sans Tabou (literally "variable geometry troupe playing without taboos). This strategy is implemented by numerous musicians. Twenty-four-year-old Fabrice, a selfemployed musician with auto-entrepreneur status, believes that "small venues" are no longer able to pay bands sufficiently beyond a certain number of musicians, and says that "you also need to know how to move things around-be able to change depending on how it might turn out." Forty-year-old Paolo, who was recently awarded a creative residency to finish his new album and prepare a tour, is similarly disillusioned:

"With the new project now, there are six of us, that's how we created the show during the residencies, and that's how we recorded the album. l'd need to find loads of gigs to promote the project, sell the record, but I can't! They're only three to six hundred euro affairs, and there are six of us, so

10 Here, the term does not refer to ordinary artists' need to do additional jobs inside or outside the art world to make a living (Bureau, Perrenoud, Shapiro 2009), but to artists branching out into different aesthetic and artistic worlds for that same purpose. 
pour vendre le disque, mais je peux pas ! C'est que des plans entre trois cent ou six cent euros, et on est six, alors c'est pas possible... Et tout le monde est intermittent, je peux pas leur demander de venir pour rien, je veux pas... Je vais devoir les faire quand même, ces dates, pour faire connaitre le projet, donc je les ferai en solo, ou en duo si il y a le budget. Mais tu comprends, ça me gave de passer autant de temps pour monter un truc bien, avec des arrangements travaillés, des chœurs, bosser des mises en place... et d'aller le jouer seul avec ma gratte ! » (Paolo, 40 ans, auteur-compositeur-interprète intermittent, père ouvrier et mère au foyer.)

Le nombre de professionnels (artistes ou techniciens) mobilisés pour une représentation est donc adapté au budget de l'employeur ou du programmateur. Cette forme d'hétéronomisation de la production artistique, qui impose la prise en considération de principes extérieurs (ici économiques) au champ artistique, n'est pas une nouveauté mais elle semble se faire plus pressante depuis les dernières décennies ${ }^{11}$. Pour autant, si cette stratégie met en difficulté les musiciens intervenants, mobilisés ou non selon les opportunités offertes, elle ne remet pas fondamentalement en cause la démarche de celui ou celle qui porte le projet artistique. La nécessité impose de modifier la forme du spectacle mais l'espoir d'être découvert et reconnu pour son travail de création peut être maintenu.

C'est beaucoup moins le cas en ce qui concerne le deuxième niveau de la diversification, consistant à créer (ou à intervenir

11 On observe ce même processus au niveau des politiques culturelles, voir par exemple Matz 2012. it's not going to work out... And they're all intermittents, can't ask them to come and play for nothing, I don't want to... I'm still going to have to do those gigs, though, to promote the project, so l'll do solo shows, or a two-piece if there's enough budget. But you know, it's a drag to spend that much time coming up with something really good, with elaborate arrangements, backing vocals, working on rehearsals... and then end up going to play by myself with my guitar!" (Paolo, 40 years old, singer-songwriter with intermittent status, father blue-collar worker and stay-at-home mother.)

This practice of adjusting the number of professionals (artists or technicians) on tour to the employer or booker's budget -a form of heteronomization of artistic production that requires consideration of principles beyond the artistic field (here economic ones)-is not a new development, but it is one which seems to have been used with increasing frequency in recent decades ${ }^{11}$. However, while this strategy puts other musicians in a difficult situation, as their work opportunities depend on available resources, such formal changes do not fundamentally affect the bandleader's chances of being discovered and recognized.

The same cannot be said for the second level of diversification, which consists in creating (or being involved in) very different

11 A similar process can be observed in the case of cultural policies, documented by Matz (2012). 
dans) des projets artistiques très différents les uns des autres. Cela concerne des artistes encore moins bien intégrés professionnellement et qui ne parviennent pas à tirer une activité et des revenus suffisants de leur seul projet artistique. Jouer le jeu de cette manière suppose d'avoir pleinement fait le deuil de ses aspirations à la reconnaissance et intériorisé son statut d'artiste ordinaire. Dans le monde des musiques actuelles par exemple, les artistes interrogés travaillent en moyenne dans cinq à six formations musicales différentes. L'argument est là encore économique mais la stratégie est différente. II s'agit cette fois de créer ou d'intégrer des formations dans des registres variés, donnant la possibilité de multiplier les lieux de diffusion : des projets susceptibles d'être programmés dans le réseau des scènes subventionnées, d'autres plus adaptés aux cafés-concerts, aux petits festivals locaux ou aux circuits de l'animation. Le cas de Jeff (batteur, 40 ans, parents ouvriers) et de Boris (guitariste, 30 ans, parents intermédiaires du secteur médico-social), tous deux musiciens intermittents, fournit une parfaite illustration de cette situation puisqu'avec une douzaine de formations (du trio jazz à la fanfare ska, en passant par des reprises de hard rock et des compositions de chanson française), ils couvrent à eux deux une bonne partie des circuits de diffusion des musiques actuelles existants en région. Tous les projets ne demandent pas le même investissement : dans l'un Jeff joue un rôle moteur, dans l'autre il se contente d'accompagner ; les projets de création nécessitent un rythme de travail hebdomadaire alors que les formations d'animation ne demandent qu'une répétition la veille de la prestation. Tous n'apportent pas non plus le même nombre d'emplois, ni le même niveau de salaire : les petits festivals et les cafés- artistic projects. This is a strategy used by artists who have even less of a professional footing and do not succeed in working enough and deriving sufficient income from their own artistic project. This strategy of play requires the artist to have given up on their aspirations of recognition entirely and to have internalized the status of ordinary artist. In jazz, pop, or hip-hop, for instance, interviewees would be working on five or six musical projects on average. There is an economic argument at work there, but the strategy is different. It consists in creating or joining bands, playing a range of styles to be able to play more venues: projects which lend themselves to the network of subsidized venues, others to small acoustic venues, small-scale local festivals, or functions. The cases of intermittent musicians Jeff (a 40-year-old drummer, the son of blue-collar workers) and Boris (a 30-year-old guitarist, whose parents hold mid-level positions in the medical/welfare sector) perfectly illustrate this situation: with the dozen bands in which they are active (running the whole gamut from a jazz trio to a ska brass, a hard-rock cover band and a French chanson band), the two of them cover much of the regional spectrum for the diffusion of contemporary music. Not all their projects demand the same level of commitment: Jeff is a leader in one of them and a supporting player in another. Creative projects require daily work, whereas function sets only call for a rehearsal the day before the event. The numbers of jobs and salary levels also vary: in general, small festival and coffeehouses pay little, whereas casinos, local authorities and company advisory boards tend to be more mindful of the rules governing work contracts and minimum wage. Here, Boris explains how most of his projects were conceived with possible venues in mind from the start, and speaks very 
concerts payent en général peu tandis que les casinos, les collectivités ou les comités d'entreprise respectent davantage les règles en matière de contrats de travail et de minimas salariaux. Boris explique la manière dont la plupart de ses projets ont été pensés dès le départ en fonction des lieux possibles de représentation et décrit en toute franchise le rapport parfois très distancié qu'il entretient avec eux.

«Bon, le groupe de rock, ça allie si tu veux le côté plaisir du rock et du caf'conc', parce que moi j'aime bien les bars, c'est cool... mais en gros ça fait dix à quinze dates dans l'année, pas plus... Le groupe de rockab', c'est alimentaire si tu veux, je m'éclate parce qu'on fait quand même du bon rock qui envoie le boulet, mais clairement, on l'a monté pour aller au cachet... dans les bars un peu rock ou les petits festoches du coin, ça passe bien ! Le groupe de mambo rock, c'est les mêmes musiciens, mais avec une chanteuse en plus, c'est plus soft, mais vraiment là, pareil, c'est pour aller au cachet, on y va et on fait le boulot, mais j'ai aucun intérêt là-dedans ! On n'a pas fait beaucoup de dates avec ça... Le groupe de reprises pop, à la base c'est un projet qui ne me branche vraiment pas, mais vraiment, c'est pas mon style de musique et c'est pas mon instrument, avec ce groupe je suis à la basse, mais bon je crache pas dessus, enfin je crache plus dessus, parce que ça fait des heures, on a fait pas mal de restaurants, de casinos, et puis c'est fait avec des potes... et par contre on fait de gros cachets de 150 nets, ça rattrape les petits qu'on fait dans les bars... enfin, le taff moi j'appelle ça le bal des casinos... [...] et j'a la fanfare, ça en peu de temps ça a bien pris et on tourne vraiment bien, surtout l'été, parce que là on est entré dans le circuit un peu "arts de la rue" et tout ça, et apparemment ça subventionne bien là-dedans, donc on n'a pas de mal à être payé au minimum syndical, pourtant on est nombreux... » (Boris 30 ans, guitariste intermittent, parents intermédiaires du secteur médico-social.) candidly of his sometimes very distanced relationship with them:

"Well, the rock band sort of combines the fun side of rock and coffeehouse jobs, 'cos I like bars quite a bit, they're cool... But it gives you about ten to fifteen gigs a year, not more than that... The rockabilly band is for putting food on the table, sort of, I still have a blast with it because we do nice ass-kicking rock'n'roll, but we clearly set it up to get paid... In rock bars or at small local festivals it goes down really well! The mambo rock band has the same musicians, but with an additional singer, it's softer stuff, but really, again, what it's all about is getting paid, we go and get the job done, but I'm not interested in it all! We didn't get a lot of gigs with that one... The pop covers band is a project that really doesn't turn me on, it really doesn't, it's not my instrument, either, I play the bass in that band; but I'm not dissing it either, 'cos it gives us a lot of hours, we've done quite a few restaurants, casinos, and we're doing it with mates... and actually we get nice fees, like 150 euros, net-it makes up for the small gigs in bars... well, that job I call the casino ball... And then I have the brass band, that one really caught on quickly and we do some nice touring with it, especially in summer, because that gets us into the 'street art' circuit a bit, and apparently there're a lot of subsidies up for grabs there; so we have no trouble getting paid the minimum wage, even though there're a lot of us." (Boris, 30 years old, guitar player with intermittent status, father a teacher and mother a nurse.) 
Leur effort de diversification va même au-delà de ces différents projets. Jeff, dont la compagne est professeure des écoles, a monté un spectacle musical pour enfants destiné aux écoles maternelles et primaires pour compléter son activité ; Boris, quant à lui, bénéficiant de contacts dans le milieu du théâtre, collabore avec une petite compagnie régionale qui propose un spectacle sur le thème du développement durable en collège et lycée. La multiplication des projets et des lieux de diffusion leur permet de conserver des droits ouverts à l'indemnisation du chômage au titre de l'intermittence et donc de se maintenir dans la carrière. Mais cette diversification apparaît incompatible avec l'impératif de «singularité » artistique. Ils ne se sentent pas pleinement artistes, du fait de ne pas défendre un projet artistique original (impératif d'authenticité), et ne sont pas identifiés comme tels par leurs collègues et les autres professionnels du secteur (principe de crédibilité).

Les conditions objectives dans lesquelles les artistes ordinaires mènent leur carrière les conduisent donc adopter des conduites raisonnables, c'est-à-dire ajustées aux places qu'ils occupent ou à leurs chances objectives d'atteindre une autre position. Selon la nature et le volume de leurs ressources professionnelles et sociales, cet ajustement des aspirations, presque invisible en ce sens qu'il est le produit d'une intériorisation progressive des contraintes objectives, traduit une fermeture plus ou moins importante du champ des possibles. Si la plupart des artistes ordinaires, une fois cette étape franchie, parviennent à se maintenir dans la carrière, ceux qui disposent d'un certain niveau de ressources conservent quelques chances d'évolution dans
Their efforts to diversify go even beyond their involvement in these projects. Jeff, whose girlfriend is a schoolteacher, has set up a music show for kids in kindergarten and primary schools to supplement his income. Boris has a network in theatre, and works with a small regional company that plays a show on sustainable development in secondary schools. Working on multiple projects and in multiple places allows them to remain eligible for unemployment allowance and keep their careers afloat. Yet this diversification appears incompatible with the ideal of artistic "singularity." They do not feel that they are fully artists, as they do not defend an original artistic project-hence falling short of the imperative of authenticityand are not identified as such by their colleagues and other professionals in the sector-thus lacking credibility.

The objective conditions in which ordinary artists manage their careers lead them to adopt reasonable behaviours in the sense that they are adjusted to the place they occupy and to their objective chances of reaching another position. Depending on the nature and amount of their professional and social resources, this nearly invisible adjustment of aspirations, which is the result of a progressive internalization of objective constraints, reflects the narrowing of their field of possibles. Once they have passed that stage, most ordinary artists manage to maintain their careers, but those with enough resources retain a chance of moving up in the professional space while those with fewer resources find themselves confined to the most dominated positions. 
l'espace professionnel alors que ceux qui en sont dénués se retrouvent confinés dans les positions les plus dominées.

\section{La vocation d'hétérodoxie ${ }^{12}$ : un contournement du jeu}

Une autre forme d'ajustement des aspirations passe par la remise en cause des règles et de l'enjeu du champ artistique $^{13}$. Celui-ci s'est en effet constitué autour d'un principe de désintéressement («l'art pour l'art »), reposant sur le double refus d'une création soumise à des impératifs économiques ou mercantiles ("l'art bourgeois ») et d'un art mis au service d'objectifs politiques ou militants (« l'art social ») (Bourdieu 1992). Comme on l'a vu, le processus de réduction des aspirations conduit une partie des artistes ordinaires, dont les chances objectives de réussite sont faibles, à rejeter les formes de consécration par le marché qui caractérisent le pôle de la grande production et des industries culturelles. De la même manière, on observe que des artistes dont les chances objectives d'accéder à la reconnaissance dans le pôle de production restreinte du champ artistique sont faibles voire inexistantes, remettent en cause le caractère désintéressé de l'art et promeuvent au contraire un principe d'utilité sociale. S'ils ne sont certes pas en mesure d'imposer la transformation de l'enjeu du champ, ce décentrement de l'intérêt du jeu permet d'assigner à la carrière un objectif qui

12 Selon l'expression utilisée par Boris Gobille (Gobille 2008), empruntée au romancier et essayiste espagnol Enrique Vila-Matas.

13 Celle-ci étant plus souvent analysée du point de vue d'artistes consacrés, fortement dotés en ressources efficientes et donc en capacité non seulement de contourner mais surtout de subvertir les règles du jeu et donc de (trans) former effectivement le champ. On pense bien sûr à Flaubert (Bourdieu 1992), Beethoven (Nora 1998) ou Manet (Bourdieu 2013).

\section{The vocation of heterodoxy ${ }^{12}$ : circumventing the game}

Another way of adjusting aspirations consists in challenging the rules and stakes of the artistic field ${ }^{13}$. The field was formed around a principle of selflessness (art for art's sake) that is based on refusing to submit to economic and market imperatives (bourgeois art) and to putting art at the service of political or activist objectives (social art) (Bourdieu 1995). As we have observed, the process of the reduction of aspirations leads some ordinary artists whose objective chances of success are low to reject the market consecration that characterizes large-scale production and the cultural industries. Similarly, artists whose objective chances of gaining recognition in the restricted sphere of the artistic field are slim or non-existent challenge the model of art for art's sake and promote socially useful art. While they are not in a position to change the stakes in the field, by decentring the interest of the game, they give their careers an objective that extends beyond the boundaries of the artistic field, while retaining a position (albeit a dominated one) in that field.

12 I owe this phrase to Boris Gobille (Gobille 2008), who himself borrowed it from Spanish novelist and essayist Enrique Vila-Matas.

13 This phenomenon is more often analysed with regard to consecrated artists, whose high amounts of effective resources enable them to not only circumvent but also subvert the rules of the game and actually shape and transform the field. Such artists include Flaubert (Bourdieu 1995), Beethoven (DeNora 1995) and Manet (Bourdieu 2013). 
dépasse les frontières du champ artistique, tout en conservant une position (dominée mais existante) en son sein.

Alors qu'une partie des artistes dénigre les différentes tâches d'animation ou de médiation culturelles qu'ils peuvent être amenés à réaliser (comme activité annexe ou comme contrepartie de l'octroi d'une subvention publique), d'autres les présentent comme le moteur principal de leur engagement. Dans les entretiens, certains artistes affirment ainsi prendre du plaisir à se positionner en « passeurs », à « transmettre » leur pratique et leurs connaissances à différents publics composés d'amateurs, scolaires ou non, et plus encore de publics «en difficultés». Agir pour d'autres, « être utile au monde ", apporter un peu d'attention à des personnes isolées, malades ou exclues procure un sentiment d'utilité proche de celui que l'on retrouve chez les travailleurs salariés et bénévoles du monde associatif (Hély 2009 ; Simonet 2010 ; Sinigaglia-Amadio 2011), du soin ou des services à la personne (Paperman \& Laugier 2005). Olivier, musicien de 36 ans, qui a connu son heure de gloire dans la région quelques années plus tôt, a toujours évité au maximum les activités annexes, quitte à vivre dans un relatif dénuement (issu d'une famille ouvrière touchée par le chômage, il dit être habitué à « vivre de peu »). Mais quand son activité musicale s'est trouvée fortement réduite, il a été contraint de diversifier ses activités pour ne pas perdre sa couverture chômage. Un ami musicien lui a alors proposé de faire, par l'intermédiaire d'une association dans laquelle il était impliqué, des interventions en milieu carcéral et hospitalier. II hésite longuement et accepte. Après plusieurs mois, il en tire un bilan très positif, au point qu'il lui arrive maintenant de mettre cette activité « utile » en avant lorsqu'il parle de son métier.
While some artists talk in dismissive terms about performing at various functions or doing cultural mediation jobs (which they might do in addition to their other work or as a counterpart to receiving a public subsidy), others present them as what drives their engagement. In interviews, some claim to enjoy playing the role of "passing on," or "transmitting" their practice and knowledge to a variety of amateurs in schools and elsewhere, and particularly to "struggling" publics. Acting for others, "making a difference in the world," giving some attention to isolated, ill, or excluded individuals gives them a sense of usefulness that compares to the experience related by paid and voluntary community workers (Hély 2009; Simonet 2010; Sinigaglia-Amadio 2011) and health and personal care providers (Paperman \& Laugier 2005). Olivier, a 36-year-old musician who had had his moment of glory in his region a few years before, has always tried his best to avoid such supplementary activities, at the cost of living in relative poverty (being from a working-class family with an experience of unemployment, he claims to be used to "living on little"). But when his musical activity dwindled, he was forced to diversify to avoid losing his unemployment benefits. A musician friend offered him the chance to play in prisons and hospitals for an association in which he was involved. Although he accepted very reluctantly, a few months later he speaks of this activity in very positive terms, to the extent that he sometimes emphasizes its "usefulness" when discussing his job. 
On retrouve ce type d'engagement, dans une formulation plus ouvertement militante, chez des artistes qui interviennent dans les quartiers populaires. Souvent eux-mêmes d'origine populaire et issus de l'immigration (italienne ou maghrébine dans nos entretiens), pas très à l'aise dans un « milieu » qualifié de «bourgeois ", ils revendiquent la participation à une forme d'éducation populaire. C'est le cas par exemple de David, comédien de 52 ans, fils d'une famille ouvrière italienne arrivée en France au début des années 1950. Depuis une quinzaine d'années, il anime des ateliers associatifs dans les quartiers populaires. S'il aurait probablement accordé moins de temps et d'importance à cette partie de son travail si sa carrière de comédien avait pris une autre tournure, elle constitue aujourd'hui une part essentielle de son métier, au sens où elle lui procure les plus grandes satisfactions et qu'elle « donne du sens » à son engagement professionnel.

«Dans la compagnie, moi, je suis plus en charge de la partie atelier, animation pédagogique, parce que je sais faire, parce que j'aime faire aussi. J'ai apporté une proposition d'atelier sur les quartiers de la ville [...] parce que j'y ai travaillé longtemps, avec [un metteur en scène local]. J'ai beaucoup de plaisir et de satisfaction à le faire [...] ça correspond à une conception politique du métier quand même : pour moi, les ateliers, c'est pas un à-côté ! Aller dans les quartiers, idem ! [...] S'il y a un travail à faire, c'est vers les quartiers, je veux pas idéaliser les quartiers, mais la jeunesse est là-bas, ça me semble tellement juste ! Tu sais que t'es pas là pour rien, t'es à ta place... » (David, 52 ans, comédien intermittent, père ouvrier et mère au foyer.)
This type of engagement is also found in more openly activismoriented formulations in artists working in disadvantaged neighbourhoods. Being often from a working-class, immigrant background (Italy or North Africa here), these artists are uncomfortable in the "bourgeois" world of art, and highlight their involvement in a form of popular education. This is the case for 52-year-old actor David, the son of Italian workers who moved to France in the early 1950 s. He has been leading associative workshops in poor neighbourhoods for around fifteen years. While he would probably have given less time and significance to that side of his work if his acting career had turned out differently, it now constitutes an essential part of it, in the sense that it offers him the greatest satisfaction and "gives meaning" to his professional engagement.

"In the company, I'm more in charge of the workshops, the educational activities, because I know how to do that stuff, and I like to do it, too. I came in with a proposal for a workshop for the city's neighbourhoods... because l've worked there for a long time [with a local director]. I get a lot of enjoyment and satisfaction out of it... it reflects a political conception of the job, I have to say: those workshops are not just something I do on the side. The same goes for going to those neighbourhoods... If there's work to be done, it's with those [disadvantaged] neighbourhoods, I don't want to idealize them, but the kids are there, it just seems so right to me! You know you're not going there for nothing, you're in your place." (David, 52 years old, actor with intermittent status, father blue-collar worker and stay-at-home mother.) 
Outre leurs origines sociales populaires et immigrées, ces artistes ont souvent en commun une certaine trajectoire militante. David n'a « jamais été encarté » mais il a participé à de nombreuses mobilisations et, de manière plus ou moins active, à des mouvements pacifistes, écologistes et antilibéraux. Saïd (57 ans, comédien et metteur en scène, enfant d'ouvriers immigrés algériens), qui anime également des ateliers dans les quartiers populaires avec une visée explicitement politique et émancipatrice, a quant à lui milité dans des organisations syndicales et partisanes communistes, avant de rejoindre des mouvements d'inspiration plus libertaires. L'un comme l'autre tentent par ailleurs d'avoir cette même exigence d'utilité politique (fournir des outils critiques pour penser le monde social) dans leur pratique artistique : une bonne pièce, explique Saïd, est celle " qui fait réfléchir » et qui surtout « donne envie d'agir ». Leur socialisation militante favorise une « vocation d'hétérodoxie » : à la fois insuffisamment dotés en ressources efficientes et porteurs de dispositions en partie opposées aux normes dominantes du champ artistique, leurs dispositions militantes les conduisent à concevoir le principe d'utilité politique de l'art comme un instrument d'« ennoblissement 》 de leur activité (Bajard \& Perrenoud 2013) et à y trouver une façon satisfaisante de vivre (de) leur métier.

Mais là aussi, on observe un ajustement fort entre les aspirations et la position occupée : «T'es à ta place », explique David. Le choix, largement déterminé par leur trajectoire sociale et professionnelle, d'une pratique artistique tout ou partie subordonnée à son utilité sociale et/ou politique, contribue, comme les stratégies de diversification, à confiner
In addition to their working-class, immigrant social backgrounds, these artists often have similar trajectories of activism in common. David has never been a "card-carrying member" of any organization, but he has participated in many demonstrations and been involved more or less actively in pacifist, ecologist, and anti-liberal movements. Saïd (a 57-yearold actor and director, the son of Algerian immigrant workers) also leads workshops in disadvantaged neighbourhoods with explicitly political and emancipatory aims. He used to be an active member of Communist unions and parties before joining more libertarian movements. Both strive for the same goal of being politically useful (by providing critical tools to reflect on society) in their artistic practice: a good play, Saïd explains, is one that "makes people think" and, above all, "want to act." Their socialization in activism encourages their "vocation of heterodoxy:" being both insufficiently endowed with effective resources and holders of dispositions that are partly at odds with dominant standards in the artistic field, their dispositions for activism lead them to conceive the principle of art as a politically useful endeavour as an instrument for "ennobling" their activity (Bajard \& Perrenoud 2013), and have a morally (and financially) rewarding experience of their work.

Yet, in this case, too, there is a clear adjustment between aspirations and position at work-as David says, "you're in your place." The choice of partly or entirely devoting their artistic practice to social and/or political ends is largely determined by their social and professional trajectory, and just like the strategies of diversification, it contributes to 
ces artistes ordinaires aux positions dominées du champ artistique.

\section{Exit et transfert des aspirations}

L'ajustement des aspirations ne suffit pas toujours au maintien dans la profession. L'absence de reconnaissance, la précarité de l'emploi, la perte des indemnités chômage, l'usure du corps mais aussi une rupture biographique (Bessin, Bidart, Grossetti 2010) ou tout autre « tournant de l'existence » (Hughes 1996) peuvent pousser les artistes au désengagement, première étape d'un « processus de rupture professionnelle »(Denave 2015). Le désir de changer de métier, qui est un bon indicateur du degré de satisfaction au travail (Glaude 1989), est en effet répandu chez les artistes. Mais les ruptures radicales avec les mondes du spectacle restent assez rares. On le comprend aisément : les métiers à vocation fournissent aux agents un socle identitaire fort qui induit une « difficulté structurelle de penser la fin de carrière » (Sorignet 2004 : 114). La reconversion la plus spectaculaire que j'ai pu observer est celle d'Ethan, un violoniste devenu boulanger. Après une formation musicale de haut niveau, il travaille comme « supplémentaire » (intermittent) dans plusieurs orchestres régionaux et tente en parallèle les concours de titulaire. Au bout de quelques années, lassé par les échecs et la précarité, il décide de « repartir de zéro » et de passer un $\mathrm{CAP}^{14}$ de boulanger. Depuis, il a ouvert sa boulangerie et n'a plus touché son violon. L'enquête montre néanmoins que la plupart des reconversions entretiennent

14 CAP : certificat d'aptitude professionnelle. keeping these ordinary artists in the dominated positions of the artistic field.

\section{Exit and transfer of aspirations}

Adjusting one's aspirations is not always enough to maintain a career in the artistic field. The lack of recognition, insecurity of employment, loss of unemployment coverage, the practice's toll on the body, a biographical rupture (Bessin, Bidart, Grossetti 2010) or any other "turning point" (Hughes 1996) may lead artists towards disengagement, the first step of a "professional rupture process" (Denave 2015). The desire for a career change, which is a good indicator of degree of job satisfaction (Glaude 1989), is widespread among artists. Yet radical ruptures from the performing arts remain fairly rare. This can be easily explained by the fact that vocational occupations give the agents a strong sense of identity that induces a "structural difficulty in conceiving a career exit" (Sorignet 2004: 114). The most spectacular career change I have observed is that of Ethan, a violinist turned baker. After completing a high-level music education, he worked as a "sub" (under intermittent status) in several regional orchestras while sitting exams to become a fulltime member. A few years later, tired of failures and insecure work, he decided to "start again from scratch" and prepare a vocational training certificate (CAP) to become a baker. He has since opened his own bakery and never touched his instrument again. In most cases, however, new careers are doubly linked with the past career in music, as they reinvest some of the specific capital accumulated in the artistic field and allow the transfer of aspirations. 
un double lien avec la carrière passée : d'une part en mobilisant une partie du capital spécifique accumulé dans le champ artistique, d'autre part en autorisant un transfert des

aspirations.

\section{De la pratique à l'enseignement d'un art :} une reconversion en douceur

La transmission sous toutes ses formes (ateliers en milieu scolaire ou dans le secteur de l'animation socioculturelle, interventions à différents niveaux dans les écoles de pratique artistique, etc.) est une des activités secondaires les plus fréquentes des artistes ordinaires. La plupart d'entre eux vantent les mérites de l'enseignement et le bénéfice, y compris pour leur propre créativité, de la relation avec les élèves. Ce travail est néanmoins, à quelques exceptions près, considéré comme alimentaire : il permet aux artistes de stabiliser leur situation financière mais il empiète sur le temps disponible pour les activités de création. Si, au fil de la carrière, il n'est pas rare que l'enseignement finisse par occuper l'essentiel du temps de travail et procurer la quasi-totalité des revenus, ce processus ne s'accompagne toutefois pas nécessairement d'une redéfinition de l'identité professionnelle. Le passage du métier d'interprète à celui d'enseignant, qui constituent bien deux métiers différents, n'est en effet pas toujours pensé comme une reconversion. L'ancienneté de la pratique pédagogique et le maintien dans le même domaine (la musique, le théâtre, la danse) semblent favoriser un sentiment de continuité dans la trajectoire professionnelle, renforcé par le fait que l'enseignement apparaît comme « une forme de reconversion de capitaux indissociablement liés à l'acquisition

\section{From practising to teaching art: smooth career transitions}

The transmission of skills in all its forms (workshops in schools or community settings, various types of intervention in art schools, etc.) is among the most frequent secondary activities for ordinary artists. Most sing the merits of teaching and the benefits of their relationships with students, including for their own creativity. Yet, a few exceptions aside, they consider such work as a day job that puts food on the table and stabilizes their finances, but takes time they could otherwise use for their creative activities. As careers progress, teaching often ends up taking up most of their working hours and providing them with most of their income, but this does not necessarily entail the redefinition of their professional identity. The transition from performing to teaching, although they are two separate occupations, is not always conceived as a career change. Teaching for a long time-and in the same discipline (music, theatre, or dance)-appears to foster a sense of continuity in professional trajectories, which is reinforced by the conception of teaching as a "form of conversion of capital intrinsically linked to the acquisition of specific expertise which cannot be traded on other labour markets" (Sorignet 2004: 128). 
d'un savoir-faire spécifique mais non négociable sur d'autres marchés du travail » (Sorignet $2004: 128$ ).

Deux exemples de trajectoires peuvent être mentionnés. Le premier est celui d'anciens enseignants (du primaire ou du secondaire) retournant à leur premier métier. David, cité plus haut, a débuté sa carrière professionnelle en faisant « le choix de la sécurité ». Enfant d'ouvriers immigrés, il se découvre une passion pour le théâtre au lycée mais le projet de devenir comédien professionnel était alors impensable, ou tout du moins impensé. II poursuit des études de Lettres, passe le concours d'enseignant et exerce quelques années dans le secondaire. Parallèlement, il poursuit sa pratique du théâtre au sein d'une petite troupe mêlant amateurs et professionnels. À l'occasion d'une rupture biographique (un divorce), il décide de «tenter (s)a chance ». II obtient sa mise en disponibilité de l'Éducation nationale (trois ans renouvelable dans la limite de dix ans sur l'ensemble de la carrière) et, avec le soutien de sa compagnie, obtient en quelques mois son « statut d'intermittent ». Au bout de quelques années, notamment après la mise en œuvre de la réforme du régime des intermittents en 2003 , il rencontre des difficultés : il peine régulièrement à maintenir des droits ouverts à l'assurance chômage, ses revenus sont de plus en plus instables et surtout, il joue de moins en moins régulièrement. L'animation d'ateliers occupe la majeure partie de son temps de travail et occasionne de longs et fréquents déplacements, pour des conditions de travail et de rémunération très peu satisfaisantes. Arrivant en fin de disponibilité, il envisage donc sérieusement de réintégrer l'Éducation nationale.
Two examples of trajectories may be mentioned. The first is that of former teachers (in primary or secondary schools) who return to their first occupation. David, who was discussed earlier, began his professional career by making the "safe choice." The son of immigrant workers, he became passionate about theatre at secondary school, but becoming a professional actor was unthinkable for him at the time-or at least he did not consider it. He studied literature at university, took exams to become a teacher and worked in secondary education for a few years. Meanwhile, he carried on acting in a small theatre company of amateurs and professionals. Following a biographical rupture (a divorce), he decided to "try his luck." He secured leave from the national education system (three years, renewable for a period of up to ten years in his career) and, with the support of his theatre company, obtained intermittent status within a few months. A few years later, particularly after the implementation of the 2003 reform to unemployment insurance for intermittents, he is increasingly struggling to remain eligible for unemployment allowance, his income is less and less steady, and acting jobs have become scarce. He spends most of his time on school and community work, which require him to travel often and for extended periods of time in unsatisfying conditions for too little pay. As the end of his leave is coming up, he is seriously considering returning to his initial teaching career. 
Le deuxième type de trajectoire est celui d'artistes qui arrivent à un moment de leur cycle professionnel, et plus largement du cycle de vie, où le maintien d'une activité artistique d'interprète devient particulièrement éprouvant. Ce moment varie selon les artistes (âge, sexe, situation familiale, niveau d'intégration professionnelle) mais aussi selon les disciplines. Les comédiens (et dans une certaine mesure les musiciens) peuvent, lorsqu'ils sont bien intégrés professionnellement, poursuivre leur carrière tant que leur santé le leur permet (Cardon 2011) - surtout les hommes car l'horizon de carrière des femmes est plus court (Menger 1997). Mais lorsque la fatigue s'installe, l'enseignement peut constituer une honorable voie de sortie. Maurice, 58 ans, comédien et metteur en scène, se sent " usé par les déplacements, les tournées ». Après une carrière heureuse, ce fils d'ouvrier " terminerai(t) bien (s)a carrière dans un conservatoire, si possible au soleil ! " et prépare dans ce but le Diplôme d'État d'enseignement du théâtre. Pour les danseurs et les danseuses, qui figurent parmi les plus vulnérables (Honta, Juhle, Salamero 2015), la temporalité de la carrière est bien différente : autour de la quarantaine, le corps n'est plus suffisamment performant, les blessures deviennent handicapantes et rendent la reconversion inéluctable (Sorignet 2004). Le transfert des aspirations vient là aussi renforcer le sentiment de continuité entre les deux métiers. Pour Laurianne, 38 ans, qui est sur le point de mettre fin à sa carrière de danseuse, l'enseignement n'est pas si différent de son travail de chorégraphe : elle réalise une création avec ses élèves, la saison se termine par une représentation à laquelle sont invités des journalistes, des élus, des financeurs, etc.
The second type of trajectory is followed by artists who reach a point in their professional cycle, and more broadly in their life, at which maintaining an activity as a performing artist becomes particularly taxing. This stage may occur at various moments depending on the artist (age, gender, family situation, and level of professional integration are all factors) and discipline. Actors, and to some extent musicians, can continue their careers as long as their health allows it when they are sufficiently well integrated professionally (Cardon 2011)-especially men, as women have shorter career spans (Menger 1997). But when fatigue sets in, teaching can constitute an honourable exit. Fifty-eight-year-old actor and director Maurice reports feeling "worn out by travelling and touring." After a happy career, this son of blue-collar workers would "quite fancy ending [his] career in a drama schoolif possible under the sun!" and is taking a state diploma in theatre teaching for that purpose. For dancers, who are some of the most vulnerable artists (Honta, Juhle, Salamero 2015), careers have very different temporalities: around the age of 40 , the body is no longer reliable enough, injuries become a handicap and make a career change inevitable (Sorignet 2004). In this case, too, the transfer of aspirations reinforces a sense of continuity between the two occupations. For Laurianne, 38, who has just ended her career as a dancer, teaching is not very different from her work as a choreographer: she creates a show with her students, the season ends with a performance attended by journalists, local politicians, funders, etc. Forty-year old Séverine (builder father and stay-at-home mother), who does a form of contemporary dance that she describes as "less physically demanding than classical ballet" 
Séverine, 40 ans (père maçon et mère au foyer), qui pratique une forme de danse contemporaine qu'elle qualifie de moins « exigeante physiquement que du ballet classique », pense pouvoir poursuivre son activité en compagnie pendant quelques années encore. Mais, titulaire d'un DE, elle souhaite finir sa carrière dans un conservatoire. Comme Laurianne, elle voit dans cette transition des avantages en termes de stabilité d'emploi mais aussi en termes de rapport au travail de danse proprement dit. Un poste d'enseignante lui donnerait l'occasion de «travailler avec des corps formés », ce qu'elle a eu peu l'occasion de faire au cours de sa carrière professionnelle, n'ayant pratiquement jamais eu les moyens nécessaires pour faire danser une troupe de professionnels. En devenant enseignante, elle concrétiserait des aspirations qu'elle n'a jamais pu atteindre en tant que chorégraphe professionnelle.

\section{De la vocation artistique à la vocation culturelle}

Avec l'enseignement, l'occupation d'emplois « de renfort » (Becker 1988), dans la technique (de « roadie » à ingénieur du son) ou l'administration culturelle (de l'accueil des artistes à la production), est l'une des formes courantes de pluriactivité chez les artistes ordinaires et constitue ainsi une autre voie de reconversion possible. À l'image des professions concernées, ces voies sont très fortement sexuées: les métiers de la technique sont très masculins (de $65 \%$ chez les techniciens à $93 \%$ chez les cadres techniques) ; les métiers de l'administration sont plus féminisés (56\% chez les cadres de production) (Patureau 2006). Dans les deux cas, la possibilité d'une reconversion s'appuie sur la mobilisation de envisions pursuing her activities in a company for several more years. But she has a state teaching diploma, and would like to end her career at a music school. Like Laurianne, she sees advantages in that transition in terms of job stability, but also of her relationship to dance itself. A teaching position would give her the opportunity to "work with trained bodies," which she has seldom had the chance to do during the course of her professional career, having never had enough resources to work with a professional company. By becoming a teacher, she would fulfil aspirations that were always out of reach when she was a professional choreographer.

\section{From artistic to cultural vocation}

As well as teaching, having a "support" role (Becker 1982) either technical (from roadie to sound engineer) or in cultural administration (from artist management to production) -is one of the frequent forms of pluriactivity in ordinary artists and thus constitutes another possible career change option. Like the professions concerned, these paths are highly gendered: technical occupations are predominantly male (from $65 \%$ of technicians to $93 \%$ of technician managers); cultural administration jobs are more female-dominated $(56 \%$ of production managers) (Patureau 2006). In both cases, the possibility of a career change is enabled by the mobilization of specific capital and the transfer of aspirations from artistic creation to creative support. 
capitaux spécifiques et sur un transfert des aspirations de la création artistique au soutien à la création.

S'il est fréquent que les musiciens intermittents (plus de $80 \%$ d'hommes) « fassent le son » pour des amis lors d'un concert, assumant ainsi ponctuellement le rôle de technicien, le « basculement » (terme récurrent dans les entretiens) vers la technique opérationnelle est souvent vécu sur le mode du renoncement. C'est bien faute de pouvoir vivre de leur art qu'ils se « rabattent » sur ce « second métier» (Lahire 2006). Mais emprunter cette voie suppose à la fois des compétences techniques, du capital social (« le réseau dans le milieu ») et du capital symbolique (« la réputation »), dont ne sont pas également dotés tous les musiciens. Julien, 42 ans (père ouvrier et mère employée), a connu "plusieurs années de galère » en tant que bassiste avant de se réorienter progressivement vers le métier d'ingénieur du son. Ayant toujours aimé la technique, il a suivi plusieurs formations et en vit aujourd'hui confortablement. L'absence d'activité artistique est une source de frustration, mais elle est partiellement compensée par le fait de vivre non plus « de » mais " dans la musique ». Julien se sent à l'aise dans le milieu des musiques actuelles, dans lequel il a la plupart de ses amis, et retire une certaine fierté d'être un maillon important de l'existence des spectacles, et plus encore de leur qualité. Pour lui, un «bon ingé son », ce n'est pas (que) celui qui sait comment régler une console numérique dernier cri, c'est surtout celui qui « sait donner au son la couleur qui correspond à l'ambiance et au tempérament de l'artiste ». Savoir donner " une couleur au son » réclame bien sûr des compétences techniques pointues mais le vocabulaire utilisé n'est pas
While intermittent musicians (more than $80 \%$ of men) often "do the sound" for friends at shows, thus occasionally taking on the role of technician, the shift (in French basculement, a recurrent term in interviews) towards operational technique is often experienced in terms of a surrender. The reason why they "fall back" on this "second job" (Lahire 2006) is that they are unable to make a living from their art. Yet embarking on this path requires technical skills, social capital (a "network") and symbolic capital ("reputation"), which are not equally distributed among musicians. Forty-two-year-old Julien (father blue-collar worker and mother employee) "struggled for years" as a bass player before progressively turning to sound engineering. Having always liked this technical side of art, he has taken several training courses and now makes a comfortable living from the job. Not having an artistic activity is a source of frustration that is partly compensated by the transition from living "from" music to living "in music." Julien feels at ease in the world of contemporary music, where most of his friends are, and draws some pride from being an important part of what makes a show work-and what makes a show good. According to him, a "good sound engineer" is not only someone who can work a brand new digital soundboard, but someone who "knows how to give sound the colour that matches the artist's atmosphere and temperament." Giving "colour" to sound obviously requires advanced technical skills, but the language he uses is not technical (he does not talk about frequencies, compression levels, spatialization effects), belonging instead to the realm of inspiration: colour, 
technique (il n'est pas question de fréquences, de niveau de compression, d'effets de spatialisation) mais inspiré : couleur, ambiance, tempérament, etc. Mais si cette voie de reconversion permet de garder un lien fort avec les mondes du spectacle, en maintenant les liens de sociabilité tissés au cours de la carrière, la fréquentation quasi quotidienne d'artistes qui parviennent à en vivre agit aussi comme un rappel permanent de l'échec personnel. La reconversion reste alors parfois empreinte de frustration, même si le sentiment de contribuer à la réalisation des œuvres procure une forme de satisfaction professionnelle.

La démarche est à peu près similaire dans le cas des reconversions d'artistes vers l'administration culturelle, puisqu'il est à la fois question de transfert de compétences et d'aspirations. Ce type de parcours concerne surtout des comédiens, et plus encore des comédiennes. En effet, l'espace professionnel du théâtre reste plus structuré et institutionnalisé que celui de la musique ou d'autres disciplines du spectacle vivant et repose davantage sur des soutiens publics ; les opportunités d'emploi et, partant, les possibilités de reconversion dans les domaines de la production, de la diffusion ou de la communication y sont donc plus nombreuses. De plus, la raréfaction des moyens combinée à la complexification croissante des dossiers de demande de subvention et des règles de gestion rend les professionnels de la gestion culturelle de plus en plus indispensables pour les équipes artistiques. À 27 ans, Mélanie, titulaire d'une Licence de théâtre, tente de vivre depuis plusieurs années de sa pratique mais sans parvenir à stabiliser sa situation. S'occupant seule de l'administration de sa petite atmosphere, temperament, etc. But while this career change allows these people to maintain close ties with the performing art worlds by extending the social relations that have been forged during their careers, working alongside artists can also serve as a constant reminder of personal failure. In such cases career changes are tainted by frustration, even though the sense of contributing to art yields a form of professional satisfaction.

Artists whoturn to cultural administration follow a roughly similar path, in the sense that both their skills and their aspirations are transferred. This route is followed chiefly by actors, and actresses in particular. Indeed, the professional space of theatre remains more structured and institutionalized than music and other disciplines in the performing arts and draws more on public support. As a result, job (and by extension career change) opportunities in production, promotion, and communication are more abundant. Moreover, the increasing scarcity of resources, combined with the growing complexity of applications for subsidies and of management rules, makes cultural administration professionals increasingly indispensable to artistic teams. Mélanie, who has a bachelor's degree in theatre, attempted to make a living from her practice for a few years without managing to stabilize her situation. As she handled the administration of her small company by herself, she acquired basic accounting and management skills and began assisting other small local companies with those tasks. She has slowly transitioned, both objectively 
compagnie, elle a acquis des bases en comptabilité et en gestion et fait profiter de ses compétences à d'autres petites compagnies locales. Petit à petit la transition s'effectue, à la fois objectivement (elle y consacre de plus en plus de temps) et subjectivement : ce travail lui plait, elle continue à travailler dans le domaine qu'elle aime mais sans la frustration générée par les échecs de sa carrière de comédienne. À 29 ans, elle décide de reprendre une formation à l'administration culturelle à niveau master (en bénéficiant d'une validation partielle des acquis de l'expérience) à l'issue de laquelle elle s'occupe de l'administration de trois compagnies installées dans sa région et ne pratique plus du tout le théâtre. Sa vocation artistique se trouve ainsi convertie en « vocation culturelle » (Dubois

2013).

\section{Les métiers de l'accueil et du soin : retrouver la relation avec le public}

Si la reconversion dans les métiers de l'administration, de la technique et de l'enseignement relève d'une forme de transition biographique, au sens où ils constituent des débouchés somme toute assez probables pour les artistes, d'autres processus de reconversion s'apparentent davantage à des formes de bifurcation biographique, c'est-à-dire à « un changement important et brutal dans l'orientation de la trajectoire, dont à la fois le moment et l'issue étaient imprévisibles, pour l'acteur comme pour le sociologue » (Bidart 2006 : 31). C'est le cas par exemple de projets tournant autour de l'accueil et du soin. Si ces derniers nécessitent la mise en œuvre de compétences très différentes, ils reposent sur la même idée de retrouver le plaisir de la relation avec (she spends more and more time doing this) and subjectively: she enjoys the work, she continues to work in a field that she likes but without experiencing the frustration on account of repeated failures in her acting career. At 29, she decided to return to university to pursue a master's in cultural management (under the VAE procedure), after which she spent her time managing three local companies, no longer acting at all. Her artistic vocation was thus converted into a "cultural vocation" (Dubois 2015).

\section{Hospitality and healthcare jobs: reconnecting with the public}

While branching out into management, technical, or teaching jobs is a form of biographical transition in the sense that these are somewhat likely outcomes for artists, other career shifts are better described as biographical bifurcations, i.e., "major and brutal changes in the orientation of a trajectory, whose timing and outcome are unpredictable to the actor as well as to the sociologist" (Bidart 2006: 31). This applies, for instance, to career shifts towards hospitality and healthcare jobs. While the latter require putting very different skills to work, they are both based on the same idea of reconnecting with the public-a connection that is one of the sources of job satisfaction for artists (Sinigaglia 2013). 
le public, qui est une des sources du bonheur au travail des artistes (Sinigaglia 2013).

Les métiers de la restauration et de l'hôtellerie sont fréquemment évoqués par les artistes en quête de reconversion professionnelle. II ne s'agit pas d'exercer en tant qu'employé de service (serveur-euse, concierge, etc.) comme certains ont pu le faire dans le cadre de " petits boulots » complémentaires à leur activité artistique, mais d'être propriétaire ou gérant d'un lieu. Les projets de ce type sont jugés accessibles, considérations financières mises à part, au sens où ils n'impliquent pas la reprise d'études et l'obtention d'un diplôme particulier. Ceux qui l'envisagent le plus sérieusement sont les artistes qui ont eu l'occasion d'administrer une compagnie ou un collectif d'artistes. Les compétences acquises en comptabilité et en gestion constituent en effet un capital transférable dans un nouvel espace professionnel. Camille, citée plus haut, a assuré pendant quelques années l'essentiel du travail de production et d'administration de sa compagnie, l'association n'ayant pas les moyens de recourir à un intermédiaire professionnel. Elle envisage, si sa situation venait à se dégrader, d'ouvrir un restaurant avec son compagnon et conçoit ce projet de reconversion comme une opportunité de transfert de compétences mais aussi de maintien de certaines aspirations au fondement de son engagement dans la carrière artistique : être dans le relationnel, faire le lien avec le public. De même, Lucien, 42 ans, comédien et programmateur de spectacles, dont le père était cafetier et la mère employée, envisage d'ouvrir une maison d'hôtes ( « un corps de ferme, quelques
Jobs in the restaurant and hotel industry are frequently mentioned by artists seeking a change of career, not with the prospect of working as a service employee (as a waiter concierge, etc.), as some have done "on the side" during their artistic career, but of owning or managing somewhere. They consider such projects accessible, regardless of the financial aspect, in the sense that they do not require them to resume their studies and get a degree. Those who most seriously envisage this are artists who have already had the opportunity of managing a company or an arts collective. Their accounting and management skills is capital that can be transferred to a new professional space. Camille (mentioned previously) for a few years did most of the production and management work in her company, which did not have sufficient resources to hire a professional. Should her situation worsen, she is considering opening a restaurant with her boyfriend. She looks at this project as an opportunity to transfer her skills, but also to safeguard some of the aspirations on which her artistic career was based: cultivating human relationships, and developing a bond with people. Likewise, Lucien, a 42-year-old actor and programmer, whose father was a cafe owner and mother an employee, is contemplating opening a guesthouse ("a farmhouse, a few rooms, a small restaurant and a stage")he sees this as a way to keep giving exposure to plays and concerts and promoting the arts to a wide audience, in employment and working conditions that he assumes will be more stable. 
chambres, un petit resto, une scène ") ; il y voit un moyen de poursuivre, dans des conditions d'emploi et de travail qu'il imagine moins précaires, son activité de diffusion de théâtres et de concerts et son désir de promouvoir le spectacle auprès d'un large public.

La relation avec le public peut être encore plus directement au cœur des stratégies de reconversion, comme on l'observe chez les quelques artistes qui s'orientent vers les métiers du care et plus spécifiquement de l'art-thérapie ${ }^{15}$. Les artistes formés (ou en cours de formation) à l'art-thérapie décrivent une homologie entre leur pratique artistique et cette forme de soin, qui tient, d'une part, aux techniques utilisées (qui demandent une maitrise du corps et de la voix) et, d'autre part, au rapport au public (les spectateurs d'un côté, les patients de l'autre). Loïc, qui se définit encore principalement comme auteur compositeur interprète, termine une formation en « thérapie énergétique et art thérapie » et espère pouvoir commencer à accueillir des patients dans les prochains mois. Pour le moment, il cherche surtout à s'assurer une forme de stabilité financière en diversifiant son activité autour des «métiers de la voix »: des concerts, des cours de chant, de la radio, des voix off mais aussi de la thérapie par la chant. Mais, s'il ne parvient plus à tirer de revenus suffisants de la musique ou que l'absence de reconnaissance devient trop pesante, il pourrait envisager de s'y consacrer entièrement.

15 Jean-Pierre Klein, psychiatre et spécialiste de IDart-thérapie, en propose cette définition : "L口art-thérapie est un accompagnement de personnes en difficulté (psychologique, physique, sociale ou existentielle) à travers leurs productions artistiques : Duvres plastiques, sonores, théâtrales, littéraires, corporelles et dansées. 》 (Klein 2007.)
A relationship with people can be even more directly at the heart of career change strategies, as is observed in the few artists who turn to an occupation in the field of care, and more specifically to art therapy ${ }^{14}$. The artists trained (or in training) in art therapy describe a homology between their artistic practice and that form of care, owing in part to the techniques used (requiring a mastery of body and voice) and to the relationship with a public (spectators or patients). Loïc, who still defines himself primarily as a singer-songwriter, is finishing a training course in "energy and art therapy," and hopes to be able to start receiving patients within the next few months. For now, he is mostly seeking to secure some form of financial stability by diversifying his activities in voice-related occupations: concerts, singing lessons, radio, voiceovers, singing therapy, etc. But if he were no longer able to derive enough income from music, or if the lack of recognition should become too big a burden, he might consider devoting his entire time to these activities. For 45-year-old dancer Sandrine, the switch to art therapy was a real turning point. After a long and full professional career which gave her a great

14 Psychiatrist and art therapy specialist Jean-Pierre Klein has proposed the following definition: "Art therapy is supporting people in (psychological, physical, social, or existential) difficulty using their artistic output: visual work, sound art, theatre, literature, body art, and dance" (Klein 2007). 
Pour Sandrine, danseuse, le passage à l'art-thérapie est un vrai tournant. Âgée de 45 ans, après une carrière professionnelle riche en expériences et lui ayant procuré une importante reconnaissance professionnelle, elle a traversé ces dernières années des moments difficiles : baisse des sollicitations professionnelles, engagements dans des projets artistiques de moindre légitimité, perte de l'« intermittence ». Elle a d'abord eu recours à l'art-thérapie pour se « soigner » elle-même des frustrations générées par la fin de sa carrière de danseuse et, progressivement, elle y a vu un projet de reconversion professionnelle qui lui permettrait de conserver une partie de ce qui faisait l'intérêt de son métier : «on se sent utile quand on apporte quelque chose aux gens grâce à

l'art ».

La sortie d'un métier à vocation semble donc difficilement dissociable d'un transfert des aspirations artistiques. Le projet de reconversion, qu'il se situe objectivement dans le prolongement ou en rupture avec le métier exercé, prend appui sur les savoirs et les savoir-faire accumulés au cours de la carrière (des diplômes, des connaissances en technique ou en administration, des savoir-faire vocaux ou corporels, etc.), constituant un capital mobilisable dans un nouveau métier. Mais c'est bien la possibilité de réinvestir dans la nouvelle activité une partie du sens et des motivations de la

« vie d'artiste » qui permet aux agents de ne pas percevoir leur reconversion uniquement comme un échec. deal of recognition, she spent a few difficult years, being less in demand, working on less legitimate artistic projects and losing her intermittent status. She first turned to art therapy to "heal" from the frustration she felt during the later stages of her dancing career, but gradually came to envisage it as a possible career change that would enable her to safeguard part of what she valued in her work: "You feel useful when you bring something to people through art."

Exits from a vocational occupation appear to be generally connected to the transfer of artistic aspirations. Career change plans, whether they are objectively an extension of the former job or a rupture from it, draw on the skills and knowledge accumulated during artistic careers (degrees, technical or management knowledge, vocal or bodily skills, etc.), which form capital that can be repurposed for another job. Ultimately, it is the possibility of reinvesting part of the meaning and motivations of the artist's life into a new activity which allows the agents not to perceive their career change solely as a failure. 


\section{Conclusion}

Analyser le jeu des aspirations permet donc de mettre en évidence le lien qui existe entre, d'une part, les propriétés sociales des artistes ordinaires et, d'autre part, leur position et leur trajectoire au sein de leur espace professionnel dans le champ artistique. Si l'absence de consécration (ou de perspectives crédibles de consécration), conjuguée à la relative précarité des conditions d'emploi, ne pousse pas systématiquement et immédiatement les artistes à quitter la carrière, c'est en partie parce que toute une série de mécanismes favorise l'ajustement entre leurs espérances subjectives et leurs chances objectives. Ces mécanismes ne sont pas automatiques (on pourrait trouver des exemples d'artistes consacrés initialement peu dotés) et ne concernent pas seulement les artistes d'origine populaire, mais ces derniers sont de toute évidence les plus exposés à en subir les conséquences. Au fil des épreuves et des interactions avec les autres agents du champ (au premier rang desquels les pairs), chacun apprend à trouver et à occuper « sa place » et, dans une certaine mesure, à s'en satisfaire. C'est ainsi que les postulants les moins bien dotés, issus des milieux les plus modestes, sont les premiers à devoir revoir à la baisse leurs ambitions, généralement fondées sur des représentations idéalisées de la vie d'artiste. Étant porteurs de dispositions désajustées par rapport aux exigences du champ artistique et insuffisamment dotés en ressources efficientes, ils sont conduits à adopter des stratégies professionnelles qui rendent de plus en plus improbables une éventuelle consécration : ils « font le choix » de carrières locales et se produisent sur des scènes de moindre légitimité, certains diversifient leurs projets

\section{Conclusion}

This analysis of the ways in which ordinary artists play with their aspirations evidences the connection between the social properties of ordinary artists and their position and trajectory within their professional space in the artistic field. The combination of a lack of consecration (or of credible prospects of consecration) and fairly insecure employment conditions does not automatically and immediately lead artists towards a career exit, partly thanks to a number of mechanisms facilitating the adjustment between subjective and objective chances. These mechanisms do not function automatically (there are examples of consecrated artists who initially had little capital) and are not observed solely in artists from working-class backgrounds, but the latter are clearly those most exposed to experiencing their consequences. Through trials and interactions with other agents in the field (starting with peers), they each learn to find their "place" and to be content with it, at least to some degree. The least endowed aspirants from the most modest backgrounds are the first to have to lower their ambitions, which are generally founded on idealized representations of the artist's life. As their dispositions are not adjusted to the demands of the artistic field and they lack effective resources, they come to adopt professional strategies that make the prospect of consecration increasingly unlikely: they "choose" local careers and perform on less legitimate stages; some diversify their activities to the extent that any claim to singularity becomes impossible; others yet value heterodox postures, confining themselves to dominated positions in the artistic field. In most cases, these strategies are sufficient to allow them to keep 
artistiques rendant impossible toute revendication d'une quelconque « singularité », d'autres valorisent des postures hétérodoxes qui les confinent dans des positions dominées du champ artistique. Dans la plupart des cas observés, ces stratégies sont suffisantes pour permettre le maintien dans la profession. Lorsque, pour différentes raisons (précarisation économique, changement dans la situation familiale, rupture biographique, etc.), tel n'est plus le cas, on observe surtout des formes de reconversions professionnelles qui autorisent un transfert de tout ou partie des compétences (artistiques ou non) accumulées mais aussi des aspirations décrites comme le moteur de l'engagement dans la carrière.

Les origines et trajectoires sociales ne sont bien sûr pas les seuls éléments qui interviennent dans la distribution des places au sein du champ artistique. La localisation géographique, notamment la distinction entre Paris et la province (Menger 1993), et l'âge (Marguin 2013) jouent aussi un rôle important. De nombreux travaux ont également montré l'effet du genre dans la production des inégalités d'accès et de réussite dans les carrières artistiques, notamment chez les musiciennes (Buscatto 2003 ; Ravet 2011). L'articulation entre la sphère professionnelle et la sphère domestique vient encore renforcer les inégalités entre les hommes et les femmes, ces dernières ayant plus souvent la charge des activités domestiques et familiales, ce qui les rend moins disponibles pour leur activité proprement artistique (création ou participation à des projets originaux) et rejaillit sur leur carrière (SinigagliaAmadio \& Sinigaglia 2015 ; 2017). II faudrait également interroger, comme l'ont rappelé les récents débats dans les médias français sur l'absence de « diversité » (euphémisme pursing their career. When, for different reasons (economic instability, a change in family situation, biographical rupture, etc.) this is no longer the case, career changes tend to be conducive to the transfer of part or all of the skills (artistic and otherwise) accumulated but also of aspirations described as drivers of engagement in the career.

Social origin and trajectories are of course not the only factors involved in the distribution of place within the artistic field. Geographical location, especially in terms of Paris versus the rest of the country (Menger 1993), and age (Marguin 2013) also play an important role. Many studies have also evidenced the impact of gender in the production of inequalities in access to and success in artistic careers, particularly in female musicians (Buscatto 2003; Ravet 2011). The need to juggle the professional and domestic spheres further reinforces inequalities between men and women, as the latter are more often in charge of domestic and familial activities, which makes them less available for strictly artistic activities (i.e., creating or participating in original projects) and affects their careers (Sinigaglia-Amadio \& Sinigaglia 2015; 2017). The effect of real or assumed ethnic origin should also be investigatedas attested by recent debate in the French media about the lack of "diversity" (a euphemism referring to people of black, Arab, Asians, etc. ethnicity). Ideally, researchers should be 
désignant les «Noirs », les « Arabes », les « Asiatiques », etc.) au théâtre et au cinéma, l'effet des origines ethniques réelles ou supposées. Idéalement, l'analyse devrait pouvoir tenir ensemble ces rapports sociaux de classe, de genre et de race dans une perspective intersectionnelle (Crenshaw 1991) mais sa mise en œuvre reste difficile d'un point de vue méthodologique (sans même évoquer la question des " statistiques ethniques », interdites en France). II reste que l'accumulation des travaux sur l'une et/ou l'autre dimension confirme largement l'existence de rapports de domination à l'intérieur du champ artistique et suffit, comme dans bien d'autres domaines de la vie sociale, à déconstruire le mythe de l'égalité des chances, y compris, voire surtout, dans les espaces qui valorisent le don ou le talent individuel et qui, partant, se prétendent les plus détachés des déterminismes

sociaux.

Il est à ce titre intéressant de noter que si, dans les espaces dominants du champ artistique, " le talent se donne à voir comme le principal ressort de la réussite artistique - la condition "nécessair[e]", quoique "pas suffisant[e]", de la consécration 》 (Thibault 2015), cette notion est assez largement absente des espaces dans lesquels évoluent les artistes ordinaires. En pratique, sur l'échelle des valeurs, le talentueux s'oppose à l'ordinaire. Cela ne signifie pas qu'il n'y a pas de « différences interindividuelles de capacités et de réussite » (Schotté $2013: 151)$ entre les artistes ordinaires mais, précisément, que leurs qualités n'ont pas été constituées en tant que talent remarquable et remarqué. D'ailleurs, si les intermédiaires du travail artistique (agents, managers, etc.) jouent un rôle important dans les able to consider these social relationships of class, gender, and race together, in an intersectional approach (Crenshaw 1991), but this has proven difficult to implement for statistical reasons (not to mention the fact that statistics on ethnicity are banned in France). Still, the accumulated studies on several of these dimensions largely confirm the existence of relations of domination within the artistic field-as in many other areas of social life, they deconstruct the myth of equal opportunity, including if not mostly, in spaces that value individual gift or talent and that purport to be the most removed from social determinism for that reason.

In this respect, it is worth noting that, while in the dominant space of the artistic field, "talent appears to be the main driver of artistic success - the 'necessary' albeit 'insufficient' condition for consecration" (Thibault 2015), the word is largely absent from the spaces in which ordinary artists are active. In practice, on the scale of values, talented is at odds with ordinary. This does not mean that there are no "interindividual differences of skills and success" (Schotté 2013: 151) among ordinary artists, but rather that their qualities have not been recognized as remarkable (and remarked) skills. In fact, while the middlemen of artistic work (agents, managers, etc.) play an important role in the mechanisms of consecration (Lizé, Naudier Sofio 2014) and by extension in the production of inequalities in the arts (Jeanpierre 2012), 
mécanismes de la consécration (Lizé, Naudier, Sofio 2014) et donc dans la production des inégalités dans les arts (Jeanpierre 2012), ils sont assez rares dans les espaces que fréquentent les artistes ordinaires, et ceux qui s'y trouvent ne disposent généralement pas des ressources nécessaires pour « révéler » (c'est-à-dire constituer socialement) le talent des artistes qu'ils soutiennent. De ce point de vue, l'analyse conduit moins à s'interroger sur les potentielles différences de qualités (Menger 2009) entre artistes ordinaires, qu'à constater que ces derniers évoluent dans des espaces où la question n'est pas réellement posée en ces termes.

Jérémy Sinigaglia Institut d'Études Politiques de Strasbourg/SAGE (Sociétés, Acteurs, Gouvernement en Europe), CNRS UMR 7363 https://sage.unistra.fr/

\section{Références bibliographiques}

BAJARD Flora \& PeRRENOUd Marc (2013). « "Ça n'a pas de prix”. Le travail des artisans d'art ». Sociétés contemporaines, $91:$ 93-116.

BECKER Howard S. (1988). Les Mondes de l'art. Traduit de l'anglais par Jeanne Bouniort. Paris, Flammarion.

Bessin Marc, BIDART Claire, GrossettI Michel (dir.) (2010). Bifurcations. Les sciences sociales face aux ruptures et à l'événement. Paris, La Découverte.

BIDART Claire (2006). « Crises, décisions et temporalités : autour des bifurcations biographiques ». Cahiers internationaux de sociologie, 120 : 29-57.

BOURDIEU Pierre (1971). « Le marché de biens symboliques ». L'Année sociologique, 22 : 49-126. they are relatively rare in the spaces frequented by ordinary artists, and those who are there generally do not have the necessary resources to facilitate the discovery (i.e., the social acknowledgement) of the artists they support. In this sense, this research shows that considering potential differences in quality (Menger 2015) among ordinary artists is irrelevant, as these artists are active in spaces in which these aspects are not addressed in such terms.

Jérémy Sinigaglia Institut d'Études Politiques de Strasbourg/SAGE (Sociétés, Acteurs, Gouvernement en Europe), CNRS UMR 7363 https://sage.unistra.fr/

\section{References}

BajARd Flora \& PerRenoud Marc (2013). "'Ça n'a pas de prix.' Le travail des artisans d'art." Sociétés contemporaines, 91: 93-116.

BeCkER Howard S. (1982). Art Worlds. The University of California Press.

Bessin Marc, Bidart Claire, GrossettI Michel (eds.) (2010). Bifurcations. Les sciences sociales face aux ruptures et à l'événement. Paris, La Découverte.

BIDART Claire (2006). "Crises, décisions et temporalités : autour des bifurcations biographiques." Cahiers internationaux de sociologie, 120: 29-57.

BOURDIEU Pierre (1974). "Avenir de classe et causalité du probable." Revue française de sociologie, 15(1): 3-42. 
BouRdieu Pierre (1974). "Avenir de classe et causalité du probable ». Revue française de sociologie, 15(1) : 3-42.

BouRdieu Pierre (1980). Le Sens pratique, Paris, Minuit.

BouRdieu Pierre (1992). Les Règles de l'art. Genèse et structure du champ littéraire, Paris, Seuil.

Bourdieu Pierre (1993). "Effets de lieu ». In Bourdieu Pierre (dir.). La Misère du monde, Paris, Seuil, « Points » : 249-262.

BOURDIEU Pierre (2003) [1997]. Méditations pascaliennes. Paris, Seuil, «Points ».

BouRdieu Pierre (2013). Manet. Une révolution symbolique. Paris, Seuil/ Raisons d'agir.

BouRdieu Pierre (2015). Sociologie générale, vol. 1 (Cours au Collège de France, 1982-1984). Paris, Seuil/Raisons d'agir.

Brook Scott (2013). "Social Inertia and the Field of Creative Labour 》. Journal of Sociology, 49(2-3) : 309-324.

Bureau Marie-Christine, Perrenoud Marc, Shapiro Roberta (dir.) (2009). L'Artiste pluriel. Démultiplier l'activité pour vivre de son art. Villeneuve d'Ascq, Presses Universitaires du Septentrion.

BuscatTo Marie (2003). « Chanteuse de jazz n'est point métier d'homme. L'accord imparfait entre voix et instrument en France ». Revue française de sociologie, 44(1) : 33-60.

CARDON Vincent (2011). Une vie à l'affiche : sociologie du vieillissement en emploi des artistes interprètes (thèse de doctorat en sociologie). Paris, EHESS.
BouRdieu Pierre (1985). "The Market of Symbolic Goods". English translation by Rupert Swyer. Poetics, 14(1-2): 13-44.

Bourdieu Pierre (1990). The Logic of Practice. English translation by Richard Nice. Cambridge, Polity Press.

Bourdieu Pierre (1995). The Rules of Art. Genesis and Structure of the Literary Field. English translation by Susan Emanuel. Stanford University Press.

Bourdieu Pierre (1999). "Effets de lieu." In Bourdieu Pierre (ed.). The Weight of the World: Social Suffering in Contemporary Society. English translation by Priscilla Parkhurst Ferguson. Stanford University Press.

Bourdieu Pierre (2000). Pascalian Meditations. English translation by Richard Nice. Stanford, Stanford University Press.

Bourdieu Pierre (2013). Manet. Une révolution symbolique. Paris, Seuil/ Raisons d'agir.

Bourdieu Pierre (2015). Sociologie générale, vol. 1, Cours au Collège de France, 1982-1984. Paris, Seuil/Raisons d'agir.

Brook Scott (2013). "Social Inertia and the Field of Creative Labour." Journal of Sociology, 49(2-3): 309-324.

Bureau Marie-Christine, Perrenoud Marc, SHAPIRo Roberta (eds.) (2009). L'Artiste pluriel. Démultiplier l'activité pour vivre de son art, Villeneuve d'Ascq, Presses Universitaires du Septentrion.

Buscatto Marie (2003). "Chanteuse de jazz n'est point métier d'homme. L'accord imparfait entre voix et instrument en France." Revue française de sociologie, 44(1): 33-60.

CARDOn Vincent (2011). Une vie à l'affiche : sociologie du vieillissement en emploi des artistes interprètes (PhD dissertation, Sociology). Paris, EHESS. 
Coulangeon Philippe (2004). Les Musiciens interprètes en France. Portrait d'une profession. Paris, La Documentation française.

CrenshaW Kimberly W. (1991). « Mapping the Margins : Intersectionality, Identity Politics, and Violence against Women of Color ». Stanford Law Review, 43(6)

DenaVe Sophie (2015). Reconstruire sa vie professionnelle. Paris, Presses Universitaires de France.

DeNora Tia (1998). Beethoven et la construction du génie : musique et société à Vienne. 1792-1803. Traduit de l'anglais par Marc Vignal. Paris, Fayard.

DuBoIs Vincent (2013). La Culture comme vocation. Paris, Raisons d'agir.

DUVIGNAUD Jean (1965). L'Acteur. Esquisse d'une sociologie du comédien. Paris, Gallimard

Friedman Sam, O’BrIEN Dave, LAURISON Daniel (2016). «"Like Skydiving without a Parachute" : How Class Origin Shapes Occupational Trajectories in British Acting ». Sociology : 1-19.

Garcia Marie-Carmen (2011). Artistes de cirque contemporain. Paris, La Dispute.

GLAUDE Michel (1989). «Salaires et carrières des ingénieurs diplômés 》. Économie et Statistique, 221 : 33-46.

GoBILle Boris (2008). « La vocation d'hétérodoxie ». In DAMAMME Dominique, GobILle Boris, MATONTI Frédérique (dir.), Mai Juin 68. Paris, L'Atelier : 274-291.
COULANGEON Philippe (2004). Les Musiciens interprètes en France. Portrait d'une profession. Paris, La Documentation française.

CRENSHAW Kimberly W. (1991). "Mapping the Margins: Intersectionality, Identity Politics, and Violence against Women of Color." Stanford Law Review, 43(6).

Denave Sophie (2015). Reconstruire sa vie professionnelle. Paris, Presses Universitaires de France.

DeNora Tia (1995). Beethoven and the Construction of Genius: Muscial Politics in Vienna. 1792-1803. Berkeley, University of California Press.

DuBoIs Vincent (2015). Culture as a Vocation. Sociology of Career Choices in Cultural Management. English translation by Jean-Yves Bart. London, Routledge.

DUVIGNAUD Jean (1965). L'Acteur. Esquisse d'une sociologie du comédien. Paris, Gallimard.

Friedman Sam, O'Brien Dave, LaURISON Daniel (2016). “'Like Skydiving without a Parachute': How Class Origin Shapes Occupational Trajectories in British Acting." Sociology: 1-19.

Garcia Marie-Carmen (2011). Artistes de cirque contemporain. Paris, La Dispute.

GLAUDE Michel (1989). "Salaires et carrières des ingénieurs diplômés." Économie et Statistique, 221: 33-46.

GoBILLE Boris (2008). "La vocation d'hétérodoxie." In Damamme Dominique, Gobille Boris, MAtONTI Frédérique (eds.), Mai Juin 68. Paris, L'Atelier: 274-291. 
Goetschel Pascale (2004). « Décors parisiens dans Au théâtre ce soir : rituel et stéréotypes ». Sociétés \& Représentations, $17: 247-272$.

GofFMAN Erving (1973). La Mise en scène de la vie quotidienne, vol. 1, La Présentation de soi. Traduit de l'anglais par Alain Accardo. Paris, Minuit.

Gouyon Marie \& Patureau Frédérique (2014). "Tendances de l'emploi dans le spectacle ». DEPS Culture chiffres, 2.

HEINICH Nathalie (2005). L'Élite artiste. Excellence et singularité en régime démocratique. Paris, Gallimard.

Hély Matthieu (2009). Les Métamorphoses du monde associatif. Paris, Presses Universitaires de France.

Honta Marina, Juhle Samuel, Salamero Emilie (2015). " Aider à la reconversion des danseurs ». Revue française des affaires sociales, 1-2 : 229-247.

Hughes Everett C. (1996). Le Regard sociologique. Essais choisis. Textes réunis et traduits de l'anglais par Jean-Michel Chapoulie. Paris, Éditions de l'EHESS.

JEANPIERRE Laurent (2012). « De l'origine des inégalités dans les arts 》. Revue française de sociologie, 53(1) : 95-115.

JOUVENET Morgan (2006). Rap, techno, électro... Le musicien entre travail artistique et critique sociale. Paris, Éditions de la Maison des sciences de l'homme.

KaTz Serge (2007). «L'incertitude professionnelle contre la rationalisation scolaire. Le cas paradigmatique des écoles de comédien ». Cahiers de la recherche sur l'éducation et les savoirs, $6: 65-75$.

KLEIN Jean-Pierre (2007). « L'art-thérapie ». Cahiers de Gestalt-thérapie, $20: 55-62$.
GoetSCHEL Pascale (2004). "Décors parisiens dans Au théâtre ce soir : rituel et stéréotypes." Sociétés \& Représentations, 17: 247-272.

Goffman Erving (1956). The Presentation of Self in Everyday Life. Edinburgh, University of Edinburgh.

Gouyon Marie \& Patureau Frédérique (2014). "Tendances de l'emploi dans le spectacle." DEPS Culture chiffres, 2.

HEINICH Nathalie (2005). L'Élite artiste. Excellence et singularité en régime démocratique. Paris, Gallimard.

Hély Matthieu (2009). Les Métamorphoses du monde associatif. Paris, Presses Universitaires de France.

Honta Marina, Juhle Samuel, Salamero Emilie (2015). "Aider à la reconversion des danseurs." Revue française des affaires sociales, 1-2 229-247.

Hughes Everett C. (1971). The Sociological Eye, Chicago, AldineAtherton.

JeANPIERRE Laurent (2012). "De l'origine des inégalités dans les arts." Revue française de sociologie, 53(1): 95-115.

JOUVENET Morgan (2006). Rap, techno, électro... Le musicien entre travail artistique et critique sociale. Paris, Éditions de la Maison des sciences de l'homme.

KATZ Serge (2007). "L'incertitude professionnelle contre la rationalisation scolaire. Le cas paradigmatique des écoles de comédien." Cahiers de la recherche sur l'éducation et les savoirs, 6: 65-75.

KLEIN Jean-Pierre (2007). "L'art-thérapie." Cahiers de Gestalt-thérapie, 20: 55-62. 
LAHIRE Bernard (2006). La Condition littéraire. La double vie des écrivains. La Découverte.

LeHMANN Bernard (2002). L'Orchestre dans tous ses éclats. Ethnographie des formations symphoniques. Paris, La Découverte.

LizÉ Wenceslas, Naudier Delphine, Sofio Séverine (2014). Les Stratèges de la notoriété. Intermédiaires et consécration dans les univers artistiques. Paris, Archives contemporaines.

MARGUIN Séverine (2013). "Les temporalités de la réussite : le moment charnière des quarante ans chez les artistes d'art contemporain ". SociologieS. [En ligne] http://sociologies.revues.org/4466 [consulté le 23 février 2017].

MATZ Kévin (2012). « La culture au service du développement économique ou la neutralisation politique ». In DuBols Vincent (dir.), Le Politique, l'artiste et le gestionnaire. (Re)configurations locales et (dé)politisations de la culture. Bellecombe-en-Bauges, Le Croquant : 153-170.

MAUger Gérard (dir.) (2006a). L'Accès à la vie d'artiste. Sélection et consécration artistiques. Bellecombe-en-Bauges, Le Croquant.

MAUGeR Gérard (2006b). "Le capital spécifique ». In MAUGeR Gérard (dir.), L'Accès à la vie d'artiste. Sélection et consécration artistiques. Bellecombe-en-Bauges, Le Croquant : 237-253.

MENGER Pierre-Michel (1993). "L'hégémonie parisienne. Économie et politique de la gravitation artistique ». Annales. Économies, Sociétés, Civilisations, 48(6) : 1565-1600.

Menger Pierre-Michel (1997). La Profession de comédien. Formations, activités et carrières dans la démultiplication de soi. Paris, La Documentation française.
LAHIRE Bernard (2006). La Condition littéraire. La double vie des écrivains. La Découverte.

LeHMANn Bernard (2002). L'Orchestre dans tous ses éclats. Ethnographie des formations symphoniques. Paris, La Découverte.

LIZÉ Wenceslas, NAUdier Delphine, Sofio Séverine (2014). Les Stratèges de la notoriété. Intermédiaires et consécration dans les univers artistiques. Paris, Archives contemporaines.

MARGUIN Séverine (2013). "Les temporalités de la réussite : le moment charnière des quarante ans chez les artistes d'art contemporain." Sociologies. [On line] http://sociologies.revues.org/4466 [accessed on 23 february 2017].

Matz Kévin (2012). "La culture au service du développement économique ou la neutralisation politique." In DuBoIs Vincent (ed.), Le Politique, l'artiste et le gestionnaire. (Re)configurations locales et (dé)politisations de la culture. Bellecombe-en-Bauges, Le Croquant: 153-170.

MAuger Gérard (ed.) (2006a). L'Accès à la vie d'artiste. Sélection et consécration artistiques. Bellecombe-en-Bauges, Le Croquant.

Mauger Gérard (2006b). "Le capital spécifique." In Mauger Gérard (ed.), L'Accès à la vie d'artiste. Sélection et consécration artistiques. Bellecombe-en-Bauges, Le Croquant: 237-253.

Menger Pierre-Michel (1993). "L'hégémonie parisienne. Économie et politique de la gravitation artistique." Annales. Économies, Sociétés, Civilisations, 48(6): 1565-1600.

Menger Pierre-Michel (1997). La Profession de comédien. Formations, activités et carrières dans la démultiplication de soi. Paris, La Documentation française. 
Menger Pierre-Michel (2009). Le Travail créateur. S’accomplir dans l'incertain. Paris, Gallimard/Seuil.

MorinIÈRE Thomas (2007). Le Théâtre des amateurs. Un jeu sur plusieurs scènes. Bellecombe-en-Bauges, Le Croquant.

Paperman Patricia \& Laugier Sandra (dir.) (2005). Le Souci des autres. Ethique et politique du care. Paris, Éditions de l'EHESS.

PaRAdeISE Catherine (1998). Les Comédiens. Professions et marchés du travail. Paris, Presses Universitaires de France.

PATUREAu Frédérique (2006). « Le marché du travail des artistes et des techniciens intermittents de l'audiovisuel et du spectacle vivant (19872003) d'après les fichiers de la Caisse des congés spectacles ». Les Notes de l'observatoire de l'emploi culturel, 43, DEPS/Ministère de la Culture et de la Communication.

Perrenoud Marc (2007). Les Musicos. Enquête sur des musiciens ordinaires. Paris, La Découverte.

Proust Serge (2003). « La communauté théâtrale. Entreprises théâtrales et idéal de la troupe ». Revue française de sociologie, 44(1) : 93-113.

RAVET Hyacinthe (2011). Musiciennes. Enquête sur les femmes et la musique. Paris, Autrement.

SAPIRO Gisèle (2007). « La vocation artistique entre don et don de soi ». Actes de la recherche en sciences sociales, $168: 4-11$.

SIMONET Maud (2010). Le Travail bénévole. Engagement citoyen ou travail gratuit ?. Paris, La Dispute.

SINIGAGLIA Jérémy (2007). « Le mouvement des intermittents du spectacle : entre précarité démobilisatrice et précaires mobilisateurs ».
MengeR Pierre-Michel (2015). The Economics of Creativity. English translation by Steven Rendall. Cambridge, Harvard University Press.

MoRINIĖRE Thomas (2007). Le Théâtre des amateurs. Un jeu sur plusieurs scènes. Bellecombe-en-Bauges, Le Croquant.

Paperman Patricia \& Laugier Sandra (ed.) (2005). Le Souci des autres. Ethique et politique du care. Paris, Éditions de l'EHESS.

ParadeISe Catherine (1998). Les Comédiens. Professions et marchés du travail. Paris, Presses Universitaires de France.

PATUREAU Frédérique (2006). « Le marché du travail des artistes et des techniciens intermittents de l'audiovisuel et du spectacle vivant (19872003) d'après les fichiers de la Caisse des congés spectacles ». Les Notes de l'observatoire de l'emploi culturel, 43, DEPS/Ministère de la Culture et de la Communication.

Perrenoud Marc (2007). Les Musicos. Enquête sur des musiciens ordinaires. Paris, La Découverte.

Proust Serge (2003). "La communauté théâtrale. Entreprises théâtrales et idéal de la troupe." Revue française de sociologie, 44(1): 93-113.

Ravet Hyacinthe (2011). Musiciennes. Enquête sur les femmes et la musique. Paris, Autrement.

SAPIRO Gisèle (2007). "La vocation artistique entre don et don de soi." Actes de la recherche en sciences sociales, 168: 4-11.

SimONET Maud (2010). Le Travail bénévole. Engagement citoyen ou travail gratuit ?. Paris, La Dispute.

SINIGAGLIA Jérémy (2007). "The Intermittent Worker's Movement: Between a Demobilizing Precarity and Mobilizing Precarious." 
Sociétés contemporaines, 65 : 27-54. [En ligne] http://www.cairn-int.info/ article-E_SOCO_065_0027--the-protest-movement-of-the-temporary-sh. htm [consulté le 23 février 2017].

SINIGAGLIA Jérémy (2013). "Le bonheur comme rétribution du travail artistique. De l'injonction à l'incorporation d'une norme ". Sociétés contemporaines, 91 : 17-42. [En ligne] http://www.cairn-int.info/article-E SOCO_091_0017--happiness-as-a-reward-for-artistic-work.htm [consulté le 23 février 2017].

SINIGAGLIA-AmADIO Sabrina (2011). « Travail salarié et don dans le secteur associatif : des réalités qui divisent ». In JACQUOT Lionel (dir.), Travail et dons. Nancy, Presses Universitaires de Nancy : 295-312.

SinIGagliA-Amadio Sabrina \& SinIGaglia Jérémy (2015). "Tempo de la vie d'artiste : genre et concurrence des temps professionnels et domestiques ». Cahiers du genre, 59 : 195-215.

SinIGagLIA-Amadio Sabrina \& SinIGAgLIA Jérémy (2017). Les Temporalités du travail artistique. Le cas des musicien-ne-s et des plasticien-ne-s. Paris, La Documentation française.

SORIGNET Pierre-Emmanuel (2004). "Sortir d'un métier de vocation : le cas des danseurs contemporains ». Sociétés contemporaines, $56: 111$ 132.

SoRIGNET Pierre-Emmanuel (2010). Danser. Enquête dans les coulisses d'une vocation. Paris, La Découverte.

THIBAULT Adrien (2015). « Être ou ne pas être : la genèse de la consécration théâtrale ou la constitution primitive du talent ». Sociologie et sociétés, $47(2): 87-111$

ZUNIGO Xavier (2008). « L'apprentissage des possibles professionnels. Logiques et effets sociaux des Missions locales pour l'emploi des jeunes ». Sociétés contemporaines, $70: 115-131$.
Sociétés contemporaines. [On line] http://www.cairn-int.info/article-E SOCO_065_0027--the-protest-movement-of-the-temporary-sh.htm [accessed on 23 february 2017].

Sinigaglia Jérémy (2013). "Happiness as a Reward for Artistic Work. A Social Norm, form Injunction to Incorporation." Sociétés contemporaines. [On line] http://www.cairn-int.info/article-E_SOCO_091_0017--happinessas-a-reward-for-artistic-work.htm [accessed on 23 february 2017].

SINIGAGLIA-AmAdIO Sabrina (2011). "Travail salarié et don dans le secteur associatif : des réalités qui divisent." In JACQUOT Lionel (ed.), Travail et dons. Nancy, Presses Universitaires de Nancy: 295-312.

Sinigaglia-Amadio Sabrina \& Sinigaglia Jérémy (2015). «Tempo de la vie d'artiste: genre et concurrence des temps professionnels et domestiques ». Cahiers du genre, 59: 195-215.

SinIGAgliA-Amadio Sabrina \& SinIGAGLIA Jérémy (2017). Les Temporalités du travail artistique. Le cas des musicien-ne-s et des plasticien-ne-s. Paris, La Documentation française.

SORIGNET Pierre-Emmanuel (2004). "Sortir d'un métier de vocation : le cas des danseurs contemporains." Sociétés contemporaines, 56: 111-132.

SORIGNET Pierre-Emmanuel (2010). Danser. Enquête dans les coulisses d'une vocation, Paris, La Découverte.

THIBAULT Adrien (2015). "Être ou ne pas être: la genèse de la consécration théâtrale ou la constitution primitive du talent." Sociologie et sociétés, 47(2) : 87-111.

ZUNIGO Xavier (2008). "L'apprentissage des possibles professionnels. Logiques et effets sociaux des Missions locales pour l'emploi des jeunes." Sociétés contemporaines, 70: 115-131. 